This article was downloaded by: [Barbat, Alex H.]

On: 23 November 2009

Access details: Access Details: [subscription number 917022286]

Publisher Taylor \& Francis

Informa Ltd Registered in England and Wales Registered Number: 1072954 Registered office: Mortimer House, 3741 Mortimer Street, London W1T 3JH, UK

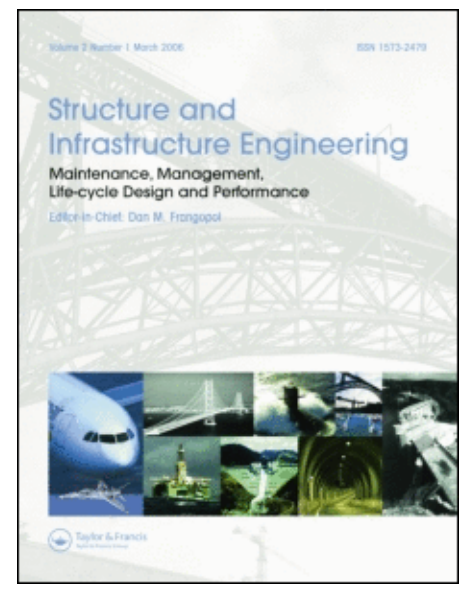

\title{
Structure and Infrastructure Engineering
}

Publication details, including instructions for authors and subscription information:

http://www.informaworld.com/smpp/title content=t713683556

\section{Seismic vulnerability and risk evaluation methods for urban areas. A review with application to a pilot area}

Alex H. Barbat a ; Martha L. Carreño ${ }^{\text {a; }}$ Lluis G. Pujades ${ }^{\text {b; Nieves Lantada }}{ }^{\text {b; }}$ Omar D. Cardona ${ }^{\text {c; }}$ Mabel

C. Marulanda ${ }^{a}$

${ }^{\text {a }}$ Department of Structural Mechanics, Civil Engineering School, Technical University of Catalonia, Barcelona, Spain ${ }^{\mathrm{b}}$ Department of Geotechnical Engineering and Geosciences, Civil Engineering School, Technical University of Catalonia, Barcelona, Spain ${ }^{\mathrm{c}}$ Universidad Nacional de Colombia, Manizales, Colombia

First published on: 24 January 2009

To cite this Article Barbat, Alex H., Carreño, Martha L., Pujades, Lluis G., Lantada, Nieves, Cardona, Omar D. and Marulanda, Mabel C.(2009) 'Seismic vulnerability and risk evaluation methods for urban areas. A review with application to a pilot area', Structure and Infrastructure Engineering, 6: 1, 17 - 38, First published on: 24 January 2009 (iFirst)

To link to this Article: DOI: $10.1080 / 15732470802663763$

URL: http://dx.doi.org/10.1080/15732470802663763

\section{PLEASE SCROLL DOWN FOR ARTICLE}

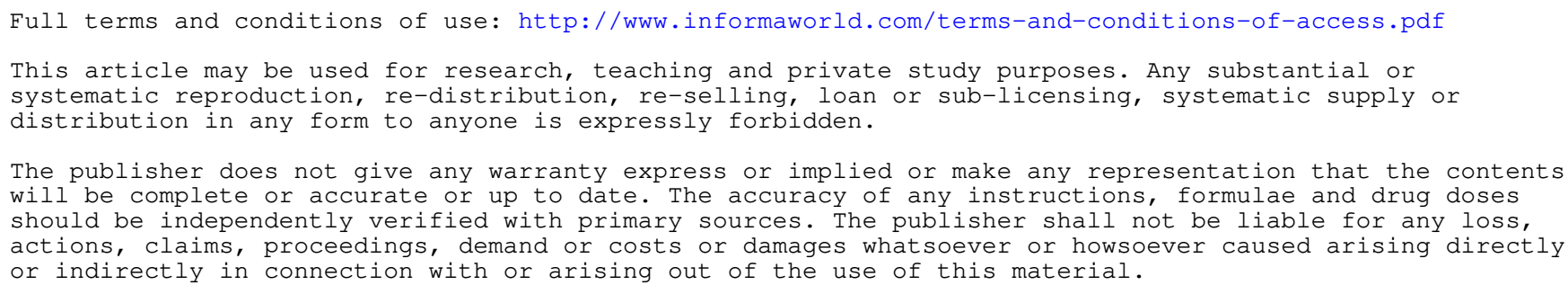




\title{
Seismic vulnerability and risk evaluation methods for urban areas. A review with application to a pilot area
}

\author{
Alex H. Barbat ${ }^{\mathrm{a} *}$, Martha L. Carreño ${ }^{\mathrm{a}}$, Lluis G. Pujades ${ }^{\mathrm{b}}$, Nieves Lantada ${ }^{\mathrm{b}}$, Omar D. Cardona ${ }^{\mathrm{c}}$ and \\ Mabel C. Marulanda ${ }^{a}$ \\ ${ }^{a}$ Department of Structural Mechanics, Civil Engineering School, Technical University of Catalonia, Edificio C1, Campus Norte \\ UPC, Jordi Girona 1-3, Barcelona, 08034, Spain; ${ }^{b}$ Department of Geotechnical Engineering and Geosciences, Civil Engineering \\ School, Technical University of Catalonia, Edificio D2, Campus Norte UPC, Jordi Girona 1-3, Barcelona, 08034, Spain; \\ ${ }^{c}$ Universidad Nacional de Colombia, Campus Palogrande, IDEA, Cra. 27 No. 64-60, Manizales, Colombia
}

(Received 16 October 2007; final version received 3 December 2008)

The most relevant seismic vulnerability and risk analysis methods are discussed and compared in this article using, as a pilot urban area, the city of Barcelona, Spain, where risk studies have been carried out over the last 15 years in the framework of different research projects. Most of the buildings in Barcelona, which have unreinforced masonry structure or reinforced concrete structure with waffled slab floors, show a high degree of vulnerability to earthquakes. The physical seismic risk but also the socio-economic implications of risk are considered in the article. The robustness of the innovative holistic approach, based on indicators related to the physical exposure, the social fragilities and the lack of resilience of urban area, is also proved. Using a geographic information system (GIS), the seismic risk results are described by means of scenarios of expected losses, but also as scenarios of probabilities of occurrence of predefined damage states.

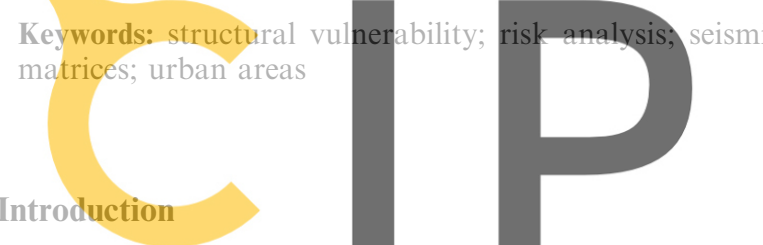

Vulnerability can be defined as an internal risk factor of an exposed element to hazard events, and corre-

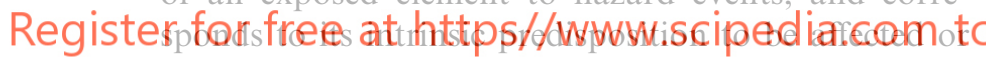
be susceptible to damage. In other words, vulnerability is the physical, economic, political or social susceptibility or predisposition of a community to suffer damage in the case of a hazard event of natural or anthropogenic origin occurring. Differences in the vulnerability of the exposed social and material context determine the selective character and severity of the effects associated with a particular event. The concept of hazard is used to refer to a latent danger or an external risk factor of an exposed element that can be expressed as the probability of occurrence of an event of certain intensity, in a specific site and during a determined period of exposure. Accordingly, risk, which is the convolution of hazard and vulnerability, is the potential expected loss to the exposed element. It can be expressed as the probability of exceedance of a given level of economic, social or environmental consequences at a certain site and during a certain period (Cardona 2004). The aim of risk studies is to

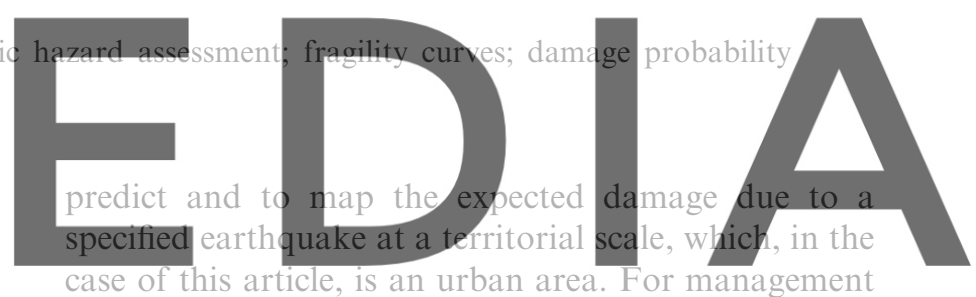
purposes, such studies have to improve decisions in

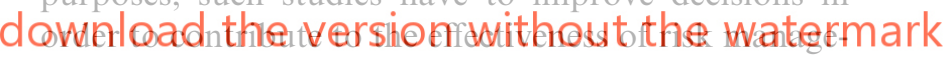
ment, concerning the action and identifying the weaknesses of the exposed element and their evolution in time (Carreño et al. 2007b).

The physical seismic vulnerability is basically related to the degree of exposure and the fragility of the exposed elements to cope with the seismic action. The comprehensive seismic vulnerability is a far more encompassing concept than that of physical vulnerability. It can be understood as the overall predisposition or the physical, economical, political or social susceptibility of a community of being affected, or of suffering damage, when an earthquake occurs. In many cases, social aspects of the vulnerability are the causes of the physical dimension of the vulnerability. The social dimension of the vulnerability is a condition that arises, grows and remains over time and is closely linked to cultural aspects and to the level of development of the communities (Cardona 2004).

*Corresponding author. Email: alex.barbat@upc.edu 
The evaluation of the physical seismic vulnerability of structures of an urban area can be carried out in the following ways:

(a) By using qualitative descriptors or variables. A qualitative descriptor classifies the buildings into vulnerability classes such as low, medium, high, etc. or A, B, C, etc. Macroseismic scales, e.g. the EMS-98 scale (Grünthal 1998), use such vulnerability definitions.

(b) By means of physical vulnerability indices. Such indices reflect the seismic quality of a building and are calculated as a function of scores attributed to the characteristics related to the structural typology, structural design and the construction practise of the buildings (Benedetti and Petrini 1984).

(c) By means of capacity curves, which are forcedisplacement diagrams corresponding to the first mode maximum response of structures. They reasonably describe the structural seismic behaviour, especially the possible damage, and are obtained by means of nonlinear structural

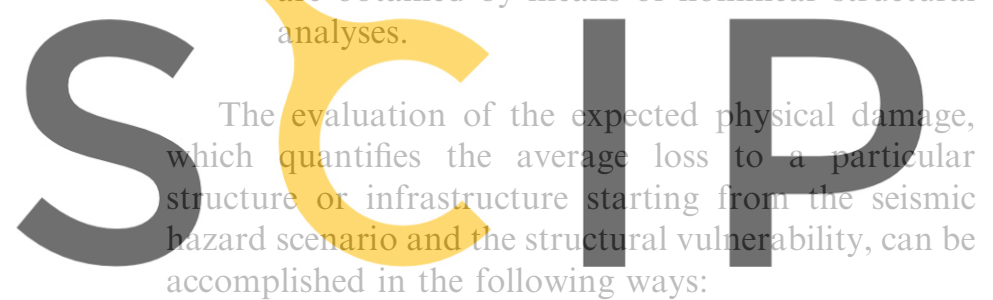

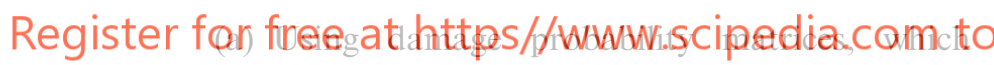
express, in a discrete form, the conditional probability $P[D=j \mid i]$ to obtain a damage level $j$, due to an earthquake of severity $i$ (Whitman et al. 1974).

(b) Using vulnerability functions, which are relations expressing the damage in a continuous form, as a function of parameters that describe the size of the earthquake and the vulnerability index (Benedetti and Petrini 1984).

(c) Using fragility curves, which express the probability that an expected global damage $d$ of a structure equals or exceeds a given damage state $d_{\mathrm{S}}$, as a function of a parameter quantifying the severity of the seismic action.

There is a close relationship between damage probability matrices and fragility curves. The difference is that fragility curves characterise the damage of a structure for any severity of the earthquakes, while damage probability matrices correspond to a concrete point of the fragility curves. These three ways of quantifying physical damage have been developed independently and over different time periods.
Nevertheless, damage probability matrices, vulnerability functions and fragility curves are now recognised as different, but equivalent, methods of quantifying the expected damage of structures. There are a number of methodologies for the estimation of vulnerability, damage and risk in seismic areas framed within these concepts (e.g. Benedetti and Petrini 1984, ATC-13 1985, HAZUS 1999). Damage probability matrices, vulnerability functions and fragility curves, obtained from structural damages observed during earthquakes, were the preferred tools in the seismic risk studies performed in the past (Benedetti and Petrini 1984, Kappos et al. 1995, Barbat et al. 1996, Singhal and Kiremidjian 1996). A complete observed damage database would be necessary in applying such approaches; however, this is only possible in high seismicity areas where properly performed postearthquake surveys are available. In areas where the data for the existing building classes and for the different seismic intensities are limited or incomplete, local expert opinion has been used to support or completely replace the probabilistic processing of the observed data (ATC-13 1985, Anagnos et al. 1995).

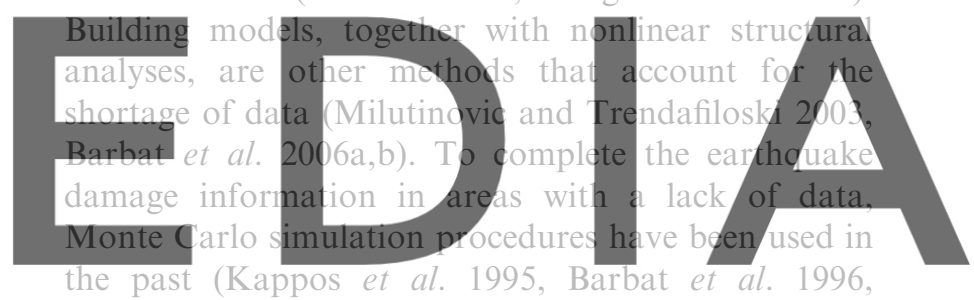
Singhal and Kiremidjian 1996). Accordingly, probabildownl aad stheoversion w it boutt theswatermark responses, obtained by applying nonlinear analysis procedures to representative buildings, provide fragility curves, damage probability matrices and vulnerability functions.

For management purposes, risk requires a multidisciplinary evaluation that takes into account not only the expected physical damage, the number and type of casualties or the economic losses, but also the conditions related to social fragility and lack of resilience, which favour the indirect effects when an earthquake strikes an urban centre. Cardona (2001) developed a conceptual framework and a model for the seismic risk analysis of urban centres from a holistic perspective, which considers both 'hard' and 'soft' risk variables. This model takes into account physical risk, exposure and socio-economic characteristics of the different units of the city and their disaster coping capacity or degree of resilience, and helps to identify the critical zones of a city and their vulnerability from the point of view of different professional disciplines. Carreño (2006) and Carreño et al. (2007a), starting from Cardona's model, developed an alternative method for the evaluation of urban seismic risk by 
means of indices. Expected damage in buildings and infrastructure obtained from simulated loss scenarios is the basic information for the evaluation of the physical damage by means of an index in each unit of analysis. The holistic evaluation of risk is also performed by using indices and is achieved by giving the physical risk an impact factor, obtained from an aggravating coefficient based on the contextual conditions, such as socio-economic fragility and lack of resilience, which worsen the initial physical effects of an earthquake.

The main objective of this article is to discuss relevant methods now used for the seismic risk analyses of buildings and of urban areas. A pilot urban area is used to show the canabilities of the different methods, namely the city of Barcelona in Spain. The city is located in an area of low seismic hazard (Egozcue et al. 1991), but its buildings have a high degree of vulnerability and, consequently, a significant probability of being damaged even in the case of moderate earthquakes. Most of the residential buildings have been designed and built without the consideration of any earthquake resistant criteria. Seismic damage previously mentioned meth for Barcelona during the

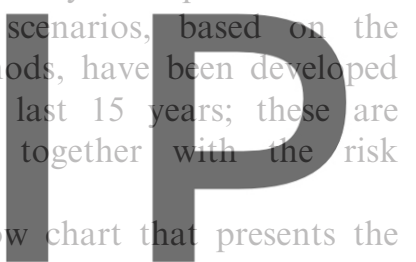

string of methods which are the objects of review in this paper, and which have been applied in the risk

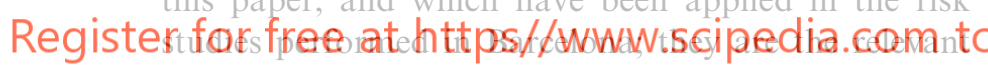

seismic vulnerability and risk analysis methods now available. The flow chart shows how, in an urban centre belonging to an earthquake prone area, studies start with a seismic hazard recognition and evaluation that, in this case, are based on probabilistic or deterministic approaches. Subsequently, seismic vulnerability is evaluated by applying methods based on capacity curves or the vulnerability. The next step is the evaluation of the physical seismic risk based on damage probability matrices, fragility curves or vulnerability functions, for the deterministic and probabilistic hazard scenarios. Finally, the holistic evaluation of the seismic risk is performed, starting from the results of the physical risk and from the social context conditions. As is pointed out in the flow chart, these methods have the final objective of supporting decision making for disaster risk management and risk reduction in the urban centre.

\section{Description of the urban pilot area}

\subsection{The city}

With a total of 1,605,602 inhabitants, (official population

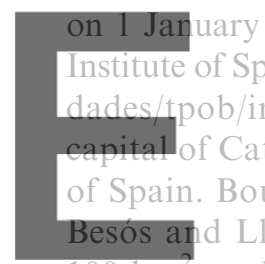

$100 \mathrm{~km}^{2}$

and an average population National Statistics
Barcelona, the
northeast coast
ridge and rivers
area/of almost

15,897 persons $/ \mathrm{km}^{2}$. At the end of the Roman period,

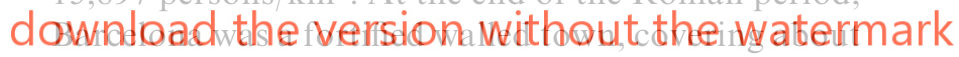

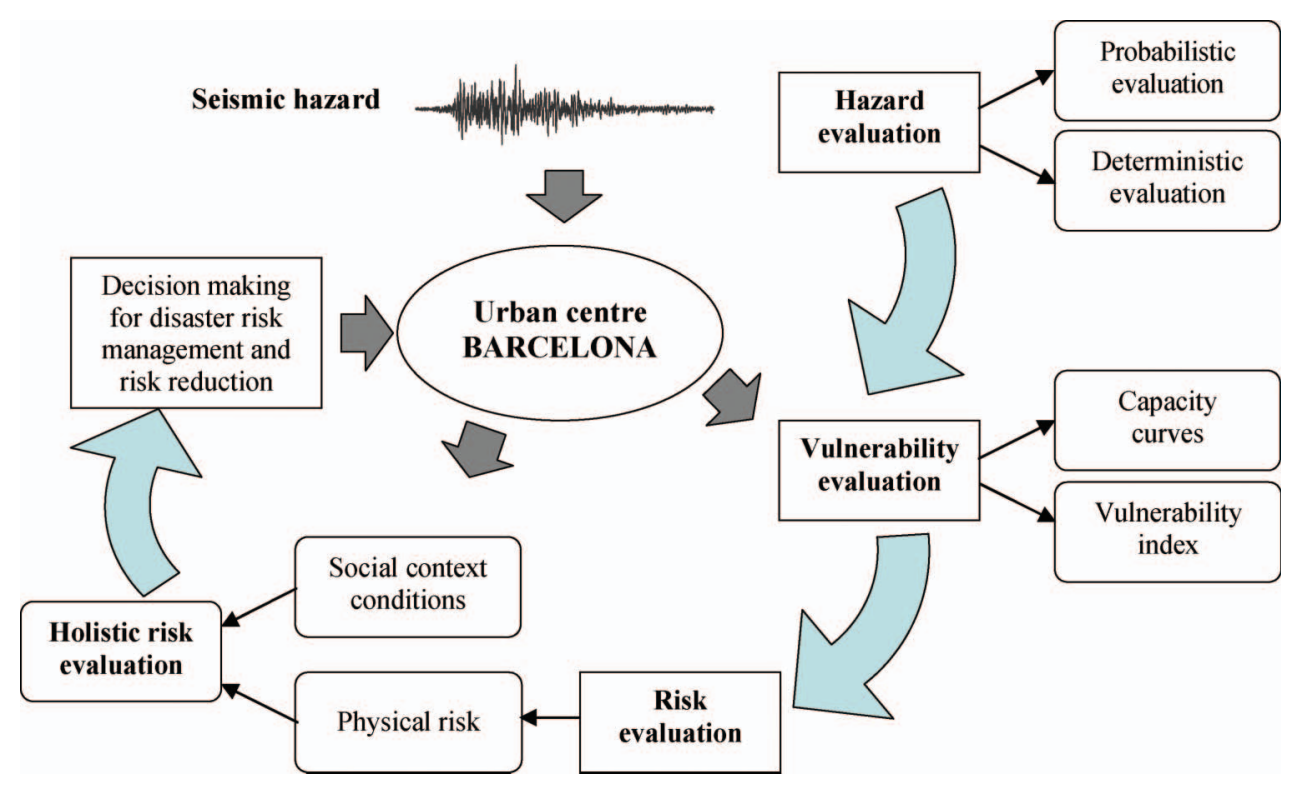

Figure 1. Flow chart presenting methods for urban seismic vulnerability and risk evaluation. 
10.5 ha and had almost 12,000 inhabitants. Barcelona's evolution into a big city began in 1868 when the adjacent towns were added to the city, which then became actual districts. Between 1910 and 1930, the population grew from 587,411 to $1,005,565$ inhabitants. Therefore, most of the city's building stock was constructed when no seismic codes were available. The presence of old buildings constructed without the use of any seismic provisions in a highly populated urban area can generate a high seismic risk, even under the effect of a moderate earthquake (RISK-UE 2004).

The city of Barcelona is subdivided into the ten districts, shown in Figure 2, which are subdivided into 38 neighbourhoods or large statistical zones. Barcelona is also subdivided into 248 small statistical zones (ZRPs). The most emblematic and representative district of Barcelona, the Eixample, covers about 750 ha in the central part of the city, was designed in the middle of the 19th century and built between 1860 and 1950

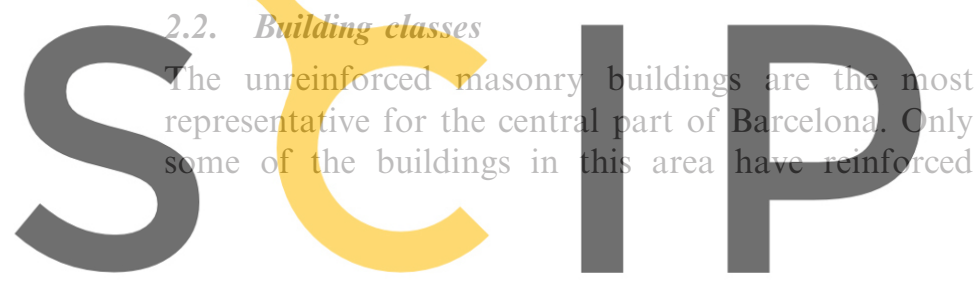

concrete structures, substituting demolished unreinforced masonry buildings, but they are more numerous in the recently built districts of the city. From the middle of the 20th century, the number of reinforced concrete buildings increased significantly in Barcelona, thus becoming the most frequent typology for new buildings. The Eixample district consists of square blocks of about $113 \times 113 \mathrm{~m}$, perfectly aligned and bevelled in their vertices by edges of about $20 \mathrm{~m}$, with an average of 25 buildings per block. The buildings were designed only for vertical static loads, without any consideration of seismic design criteria.

According to the official statistics of Barcelona (Denartament d'Estadística 2002) in the vear 2001. Barcelona had about 700,000 housings and 69,000 buildings, with an average of about 2.24 inhabitants in each. Detailed information concerning the age and typology of the buildings, geometrical features and geographical location, together with the type and year of construction of about 63,000 buildings (i.e. more than $91 \%$ of the total number of buildings), have been the starting data for the physical seismic risk evalua-

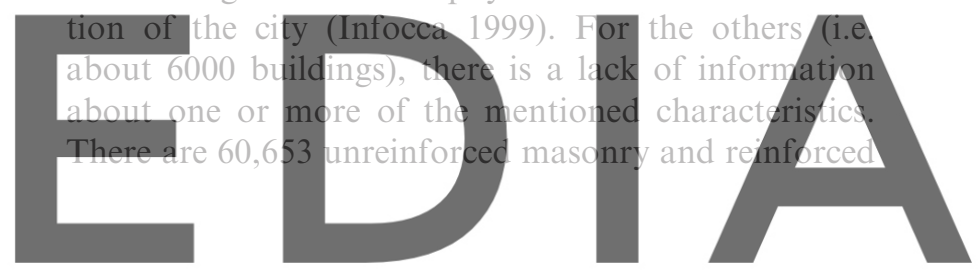

\section{Register for free at https//www.scipedia.com to dommkload the version without the watermark}

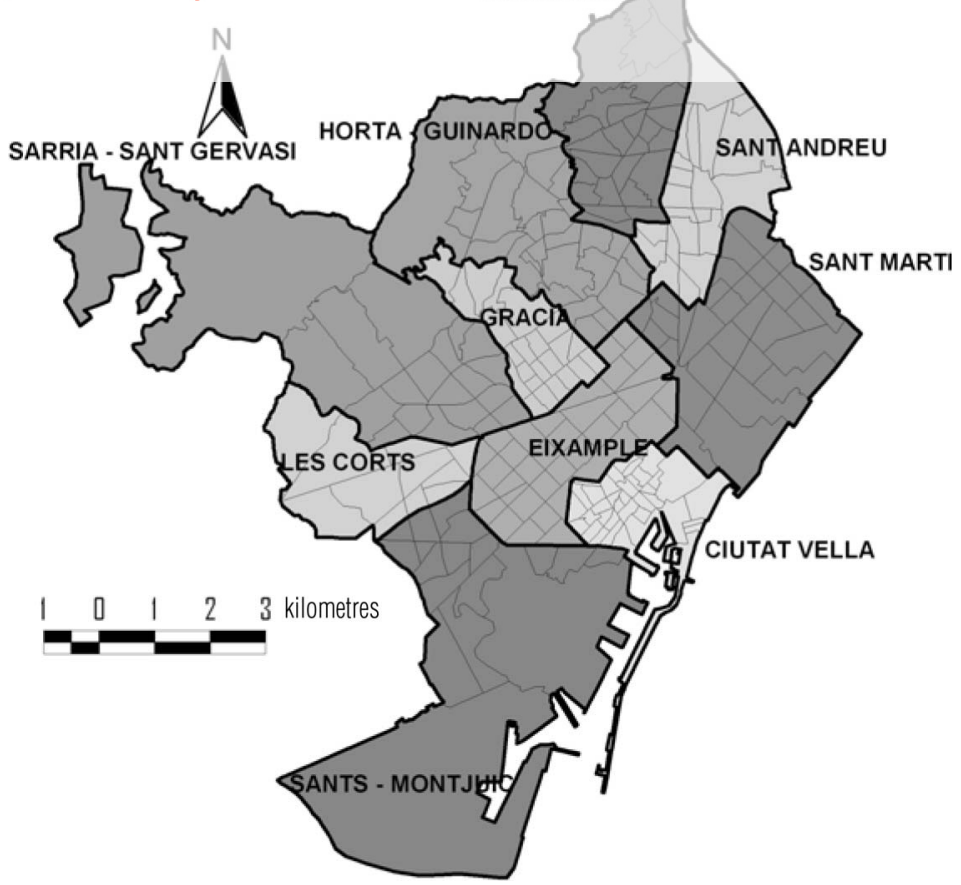

Figure 2. Territorial division of Barcelona. 
concrete buildings, which represent $96.3 \%$ of the total number of residential buildings, and only these have been included in the simulations performed in this study.

Figure 3 shows the age distribution of the buildings as a function of the constructive periods in Spain, defined by considering earthquake-resistant considerations. It can be seen that almost $80 \%$ of the building stock of Barcelona was constructed prior to the first Spanish Seismic Code (PGS-1 1968). Table 1 describes the building types. The classification codes of this table have been developed within the RISKUE European project to describe, in a detailed way, all the building types identified in Europe (Lungu et al. 2001). Figure 4 shows the building tynology distribution.

The unreinforced masonry buildings of Barcelona are tall and have openings of considerable size in their walls, which affect their vulnerability, and which is increased even more by long walls without perpendicular stiffening. Cast iron columns were used in many cases instead of masonry walls at the base and ground floors, reducing even more their lateral stiffness. lany of the buildings ar hat they have to be tensity scale, EMS-98 reinforced concrete buil oment resisting frames,
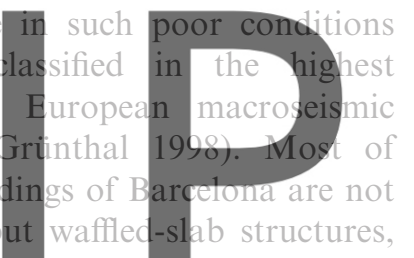
et al. (2008)). Most of them have a soft first storey.

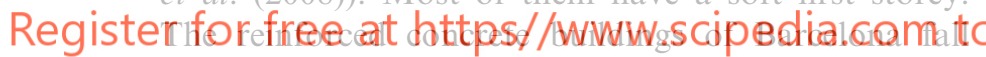
within the high vulnerability part of the EMS-98 scale, for which significant damage for relatively low seismic intensities is expected. In extreme cases, their vulnerability is comparable with that of low quality unreinforced brick masonry buildings. Detailed information on the design and construction of the buildings of Barcelona can be see in Infocca (1999), RISK-UE (2004), Barbat et al. (2008) and Lantada et al. (2008).

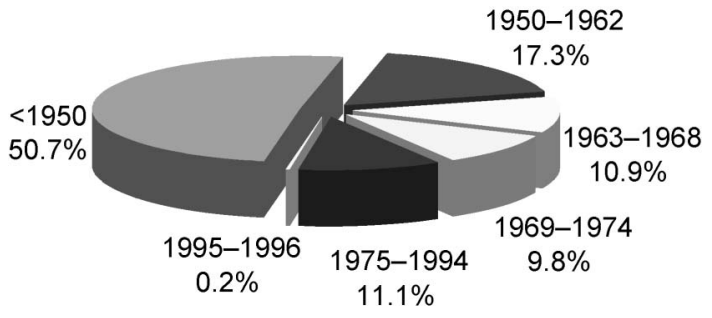

Figure 3. Distribution of buildings by age.

\subsection{Seismic hazard}

The city has moderate seismicity and weak tectonic motions. The seismic hazard of Barcelona has been recently revaluated by the Geological Institut of Catalonia (IGC). The seismic action of the city is defined in this paper by using the EMS-98 macroseismic intensities (Grünthal 1998) and by means of elastic response acceleration spectra compatible with Eurocode 8 (CEN 2004), from both a deterministic and a probabilistic point of view.

According to the seismic microzonation of Barcelona (Cid et al. 2001), based on the simulation of local effects, four zones roughly correspond to the main geological units of the soils of the city (Figure 5a). Zone R corresponds to rock outcrops (Palaeozoic and Tertiary); zone I to Holocene deposits from the Llobregat and Besós Deltas; zone II to Pleistocene formations with a Tertiary base and zone III to Pleistocene outcrops without the Tertiary basis, with sufficient thickness to have an influence on the soil amplification.

In terms of macroseismic intensities, the seismic

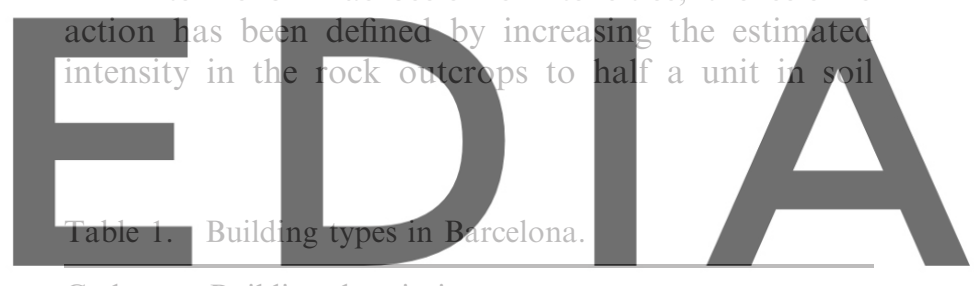

Code Building description

dowinloaditheoversioniwithout theswatermark M32 UMB with masonry vaults

M33 UMB with steel beams and masonry vaults

M34 UMB with reinforced concrete (RC) beams and masonry vaults

RC32 RC buildings with irregular structural system, irregular infill and soft/weak storeys

S1 Steel buildings with moment resisting frames

S2 Steel buildings with braced frames

S3 Steel buildings with frames with unreinforced masonry infill walls

S5 Steel and RC composite buildings

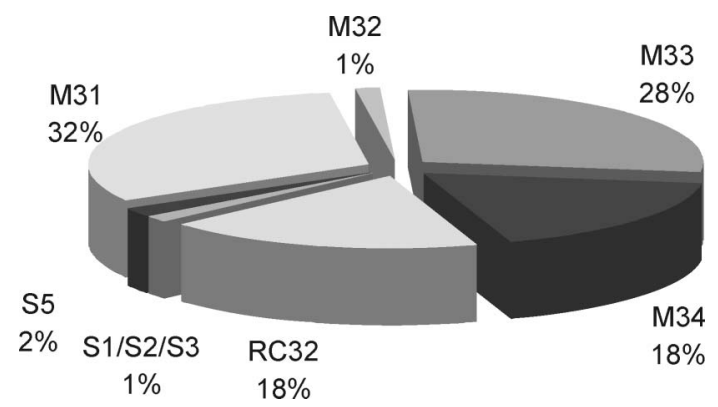

Figure 4. Distribution of buildings by typology. 

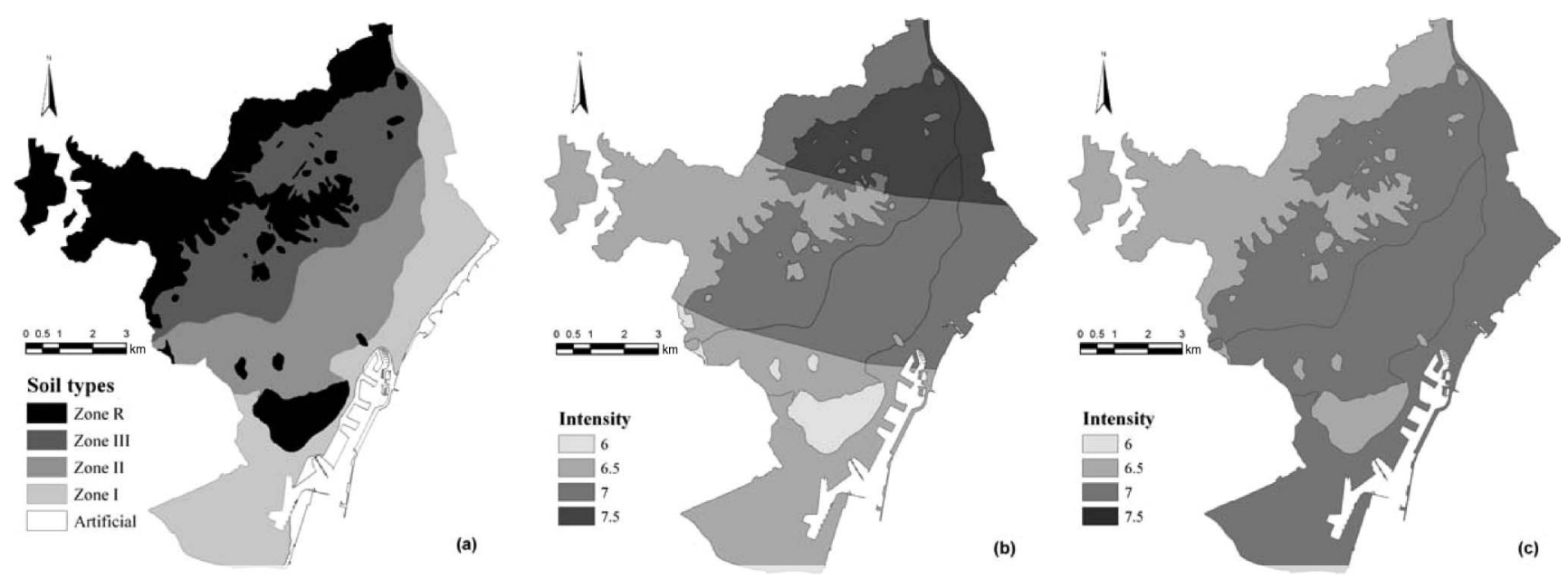

Figure 5. (a) Seismic zonation based on local effects (Cid et al. 2001), (b) deterministic scenario in macroseismic terms with soil effects and (c) probabilistic scenario in macroseismic terms with soil effects.

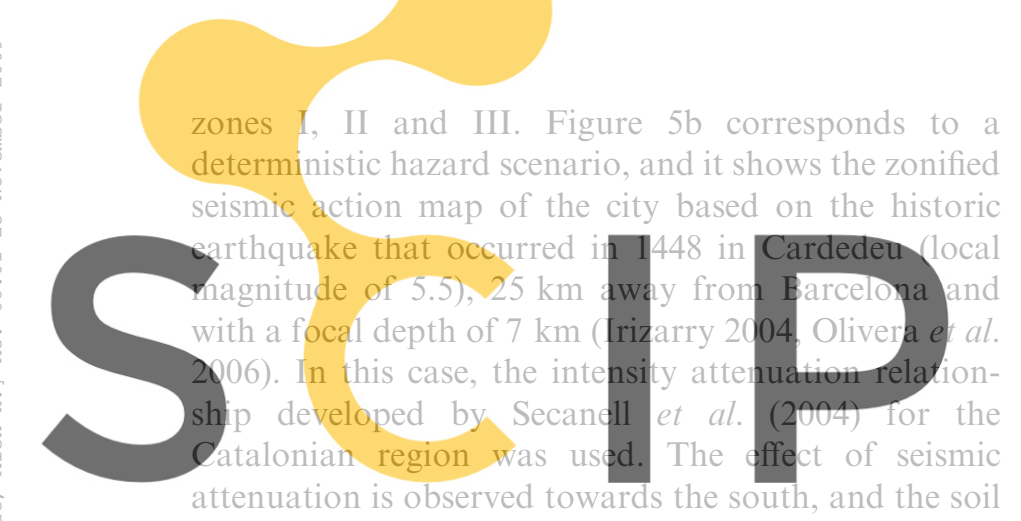

effects amplify the signal towards the east, at the sea

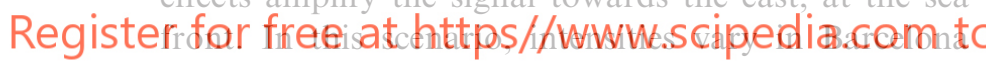
from VI, in the rock outcrop of Montjuic to VII-VIII (7.5), northeast of the city, closer to the epicentre with soft soils. A probabilistic scenario has been also developed. It corresponds to a ground motion with a $10 \%$ probability in 50 years. In this case, macroseismic intensity in the rock outcrops is VI-VII (6.5) (Secanell et al. 2004). Consequently, intensities vary from VIVII in zone R to VII in soil zones I, II and III. Figure $5 \mathrm{c}$ shows this probabilistic scenario in terms of intensity, taking into account the soil effects on the sismotectonic zonation.

In terms of $5 \%$ damping elastic response spectra for the four soil types, deterministic and probabilistic hazard scenarios were also calculated (see Figure 6) (Irizarry 2004, Barbat et al. 2008). These constitute the departure point to estimate demand spectra and performance points. The attenuation law of Ambraseys et al. (1996) was used for calculating the spectral acceleration $\left(S_{\mathrm{a}}\right)$ values. The peak ground acceleration (PGA) corresponding to the deterministic and probabilistic scenario with a $10 \%$ probability in 50 years are mapped in Figures $7 \mathrm{a}$ and Figure $7 \mathrm{~b}$, respectively. Site effects are included both in the probabilistic and deterministic seismic hazard assessment. Each zone is characterised by an average transfer function and by an amplification factor of the spectral response spectra.
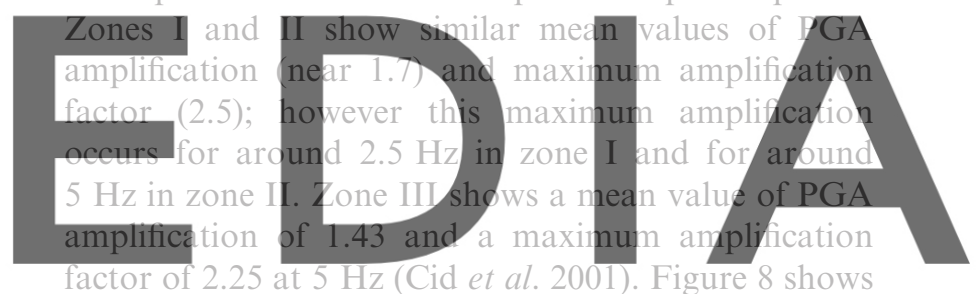

the spectral amplification functions used for each zone downhadithe sersion without the watermark

The seismic hazard for Barcelona is described in detail by Cid et al. (2001), Irizarry et al. (2003), Irizarry (2004) and RISK-UE (2004). The seismic zonation (Cid 1998, Cid et al. 2001) has been taken into account to obtain specific damage probability matrices for the buildings located in areas with different soil characteristics in Barcelona.

\section{Seismic risk assessment based on the vulnerability index}

The vulnerability index method (VIM; Benedetti and Petrini 1984) was developed based on a great amount of damage survey data corresponding to several seismic zones of Italy. The most important 11 parameters controlling the damage in buildings caused by earthquakes are identified and qualified by means of coefficients affected by weights that try to emphasise their relative importance. The mentioned parameters are: structural system organisation, structural system quality, conventional strength, retaining walls and foundation, floor system, configuration in plant, configuration in elevation, maximum distance between 


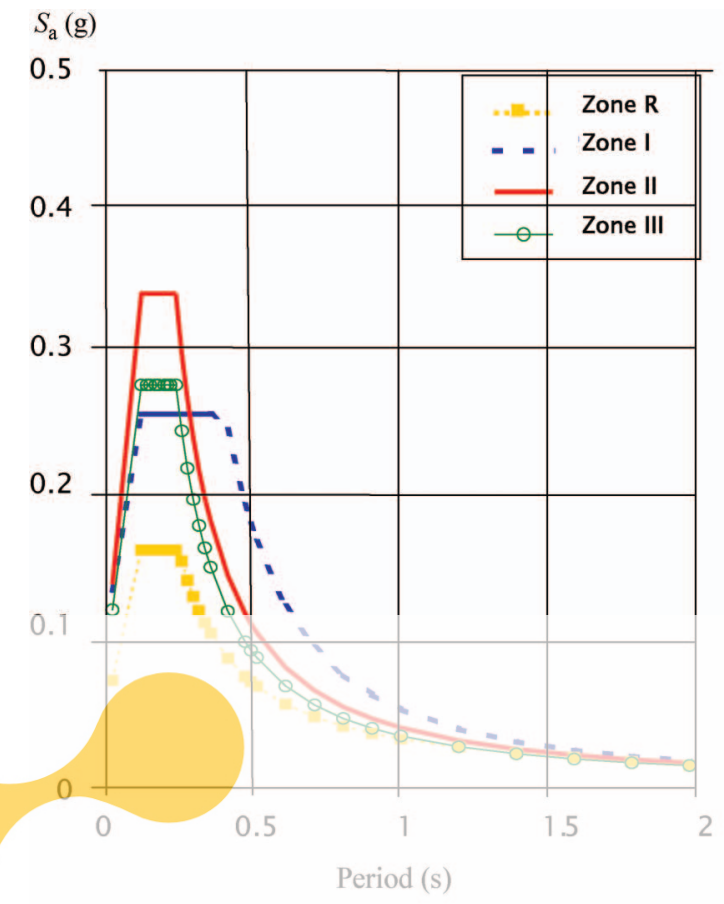

(a)

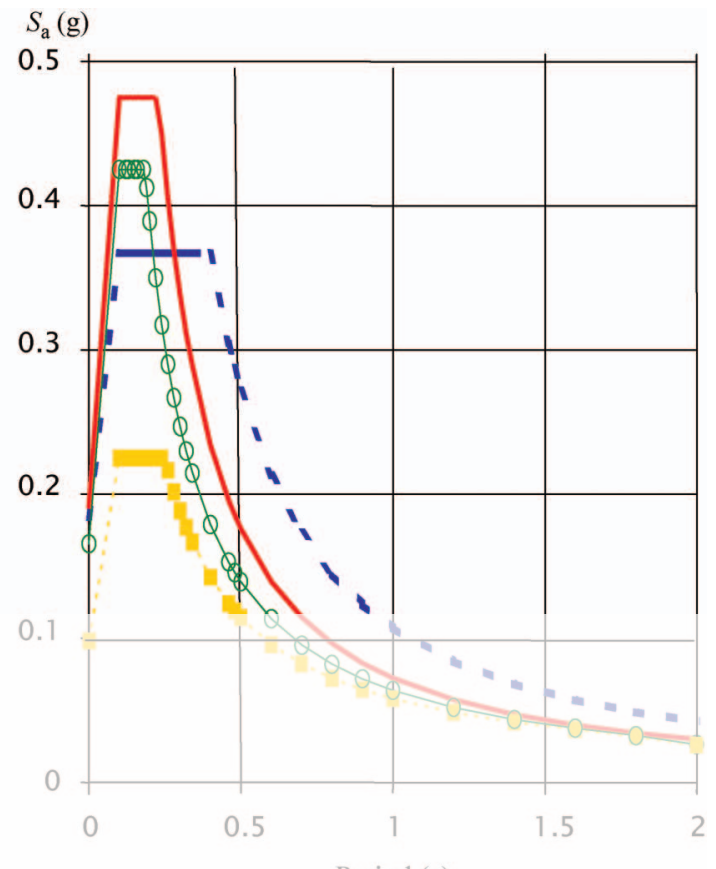

Period (s)

(b)
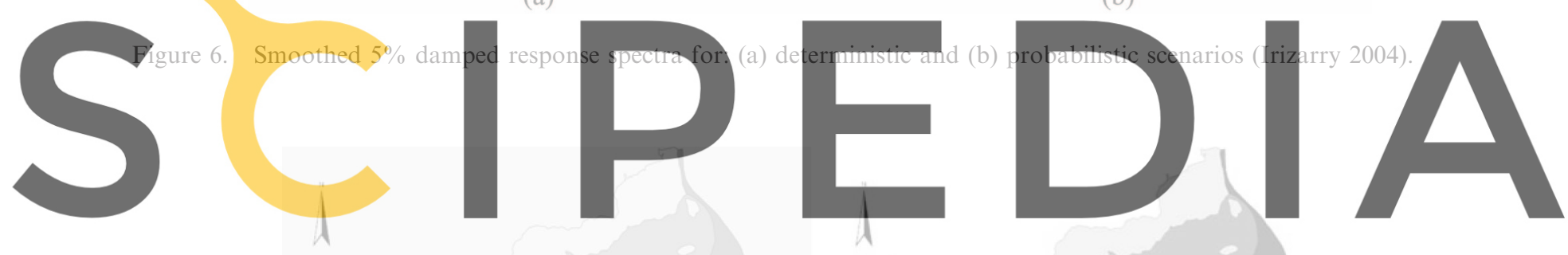

Register for free at https//www.scipedia.com to download the version without the watermark
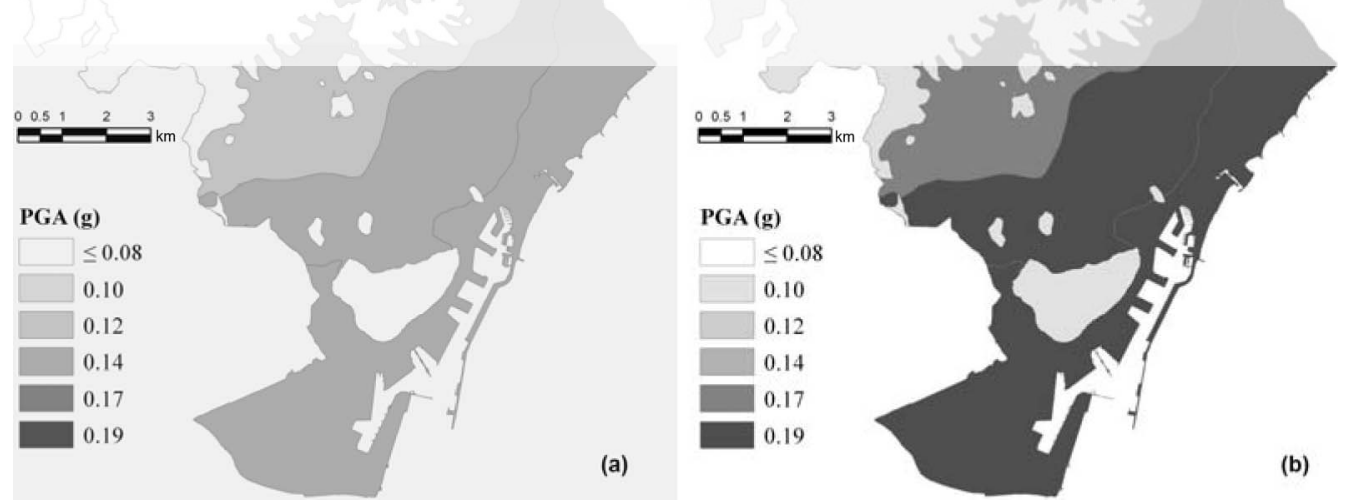

Figure 7. Seismic hazard scenario in terms of peak ground acceleration (PGA) with soil effects for: (a) the deterministic case and (b) the probabilistic case.

walls, roof type, non-structural elements and preservation state.

In 1996, the VIM was applied to the study of the seismic vulnerability of the Eixample district of Barcelona (Barbat et al. 1996, Yepez et al. 1996). The study performed a seismic damage simulation for the unreinforced masonry buildings existing in the area. A calibration procedure of the vulnerability functions using a post-earthquake damage survey and a probabilistic analysis was also proposed, in order to deduce damage probability matrices and fragility curves applicable to Spain. The post-earthquake 
damage survey data obtained after the 23 December 1993 and 4 January 1994 earthquakes in the south of Spain were used for calibration. This earthquake had intensity VII on the Medvedev-Sponheuer-Karnik (MSK) macroseismic intensity scale used at that time in Spain and in other European countries. The

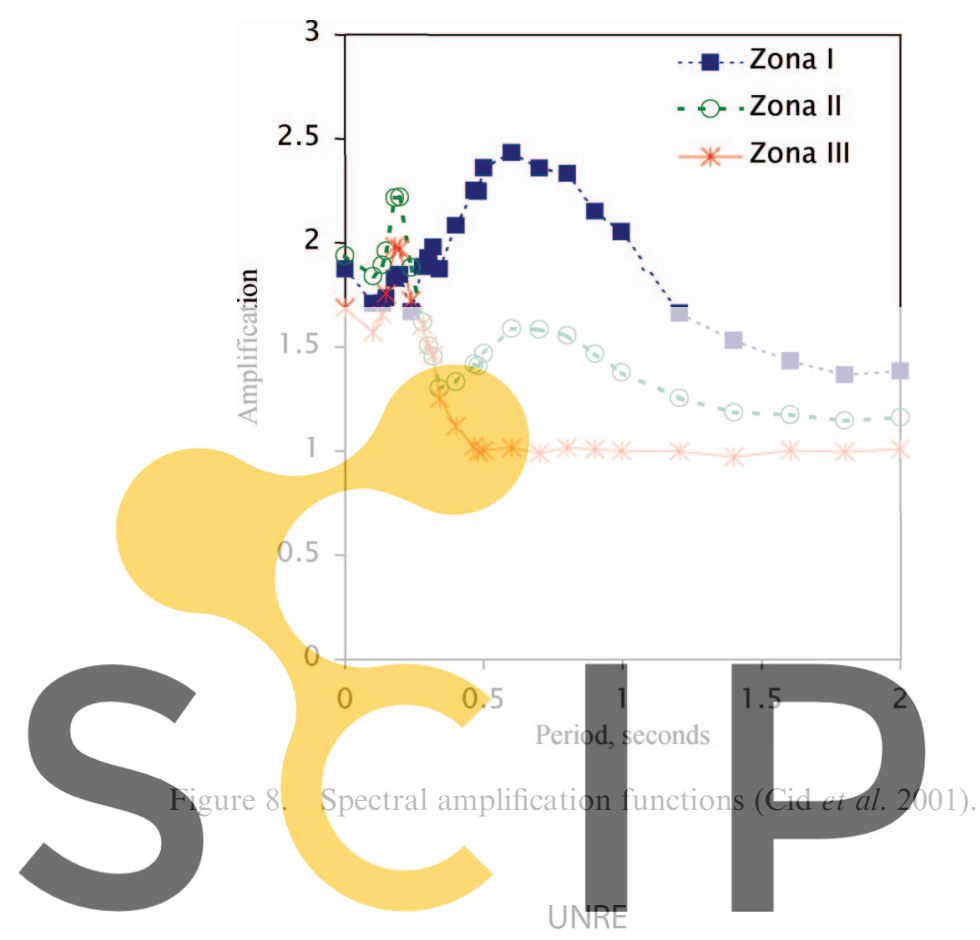

vulnerability function corresponding to this intensity (VII MSK) was first developed using the 8 surveys and the vulnerability analyses of the affected buildings. Other vulnerability functions, for other intensities, were developed using a computer simulation process and a probabilistic analysis. Figure 9 shows the developed vulnerability functions.

The vulnerability functions of Figure 9 were used to evaluate the average damage of the buildings of nine blocks of the Eixample district of Barcelona. Figure 10a shows the vulnerability index $\left(I_{\mathrm{v}}\right)$ calculated for each of these buildings. The vulnerability index was classified into five levels: low $\left(I_{\mathrm{V}} \leq 140\right)$, medium-low $\left(140<I_{\mathrm{V}} \leq 180\right)$, medium $\left(180<I_{\mathrm{V}} \leq 220\right)$, high $\left(220<I_{\mathrm{V}}<260\right)$ and very high $\left(I_{\mathrm{V}}>260\right)$.

Figure $10 \mathrm{~b}$ shows the damage scenario obtained using these vulnerability indices and the vulnerability functions of Figure 9 for an earthquake having an intensity of VII on the MSK scale.

Barbat et al. (1998) applied the VIM, as proposed by Barbat et al. (1996), to the whole district of Eixample, and Mena (2002) applied it to the entire city of Barcelona. More recently, an updated version

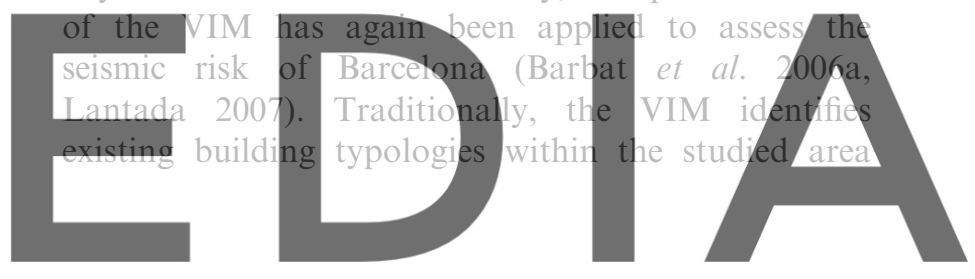

Register for free at https//wWw.scipendia.comnto downlodd the fversion/without the watermark

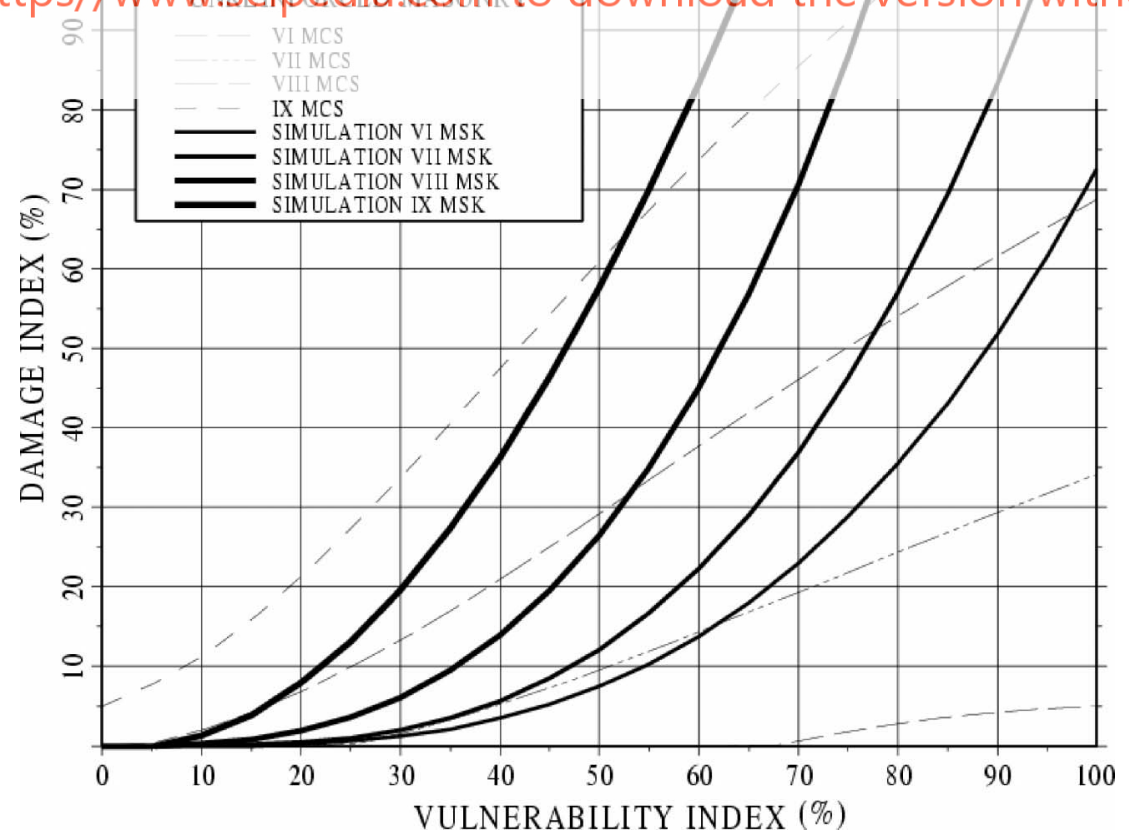

Figure 9. Vulnerability functions for the simulated unreinforced masonry buildings for different MSK vulnerability levels. The 9 thin non-continuous lines corresponds to the Italian vulnerability functions proposed by Angeletti et al. (1988) and expressed using the Mercalli-Cancani-Sieberg (MCS) macroseismic intensity scale. 
and defines their vulnerability class (Table 2). In this VIM version, vulnerability indices are normalised taking values between 0 (least vulnerable buildings) and 1 (most vulnerable buildings). For each vulnerability class, the relationship between intensity and damage may be defined by using damage probability matrices. The specific buildings of Barcelona are classified into different groups that are characterised by a similar seismic behaviour. All the buildings belonging to each typology are cast within the most probable class. Figure 11 shows vulnerability maps for unreinforced masonry and reinforced concrete buildings.

This vulnerability analysis shows the low seismic quality of the dwellings in the city, which is typical for cities located in areas with low hazard, as there is no concern for seismic-resistant protection. The

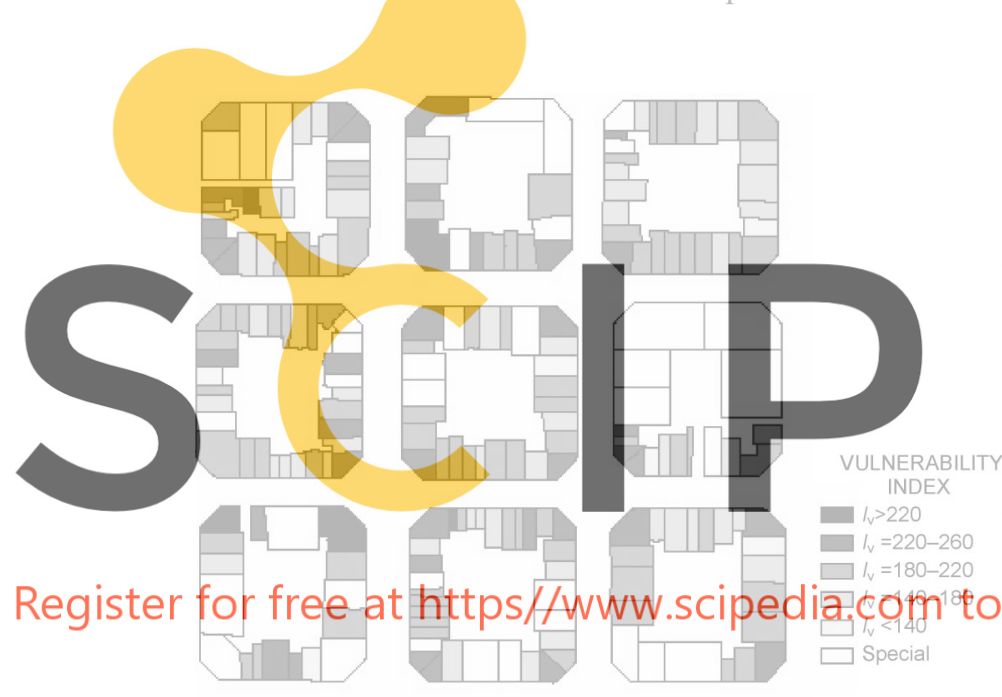

(a) methodology uses six damage states: a no-damage state (denoted as none), slight, moderate, substantial to heavy, very heavy and collapse. A sort of mean damage grade, $\mu_{\mathrm{D}}$, permits the expected damage for a building to be characterised completely, for a given intensity, if its vulnerability is known. Damage probability matrices were obtained by assuming a beta probability density function for the damage probability. Figure 12 shows the mean damage grade assessed, based on the VIM.

\section{Physical seismic risk based on capacity curves}

\subsection{Capacity curves}

The most recent trends in the field of vulnerability evaluation for risk analysis operate with simplified 

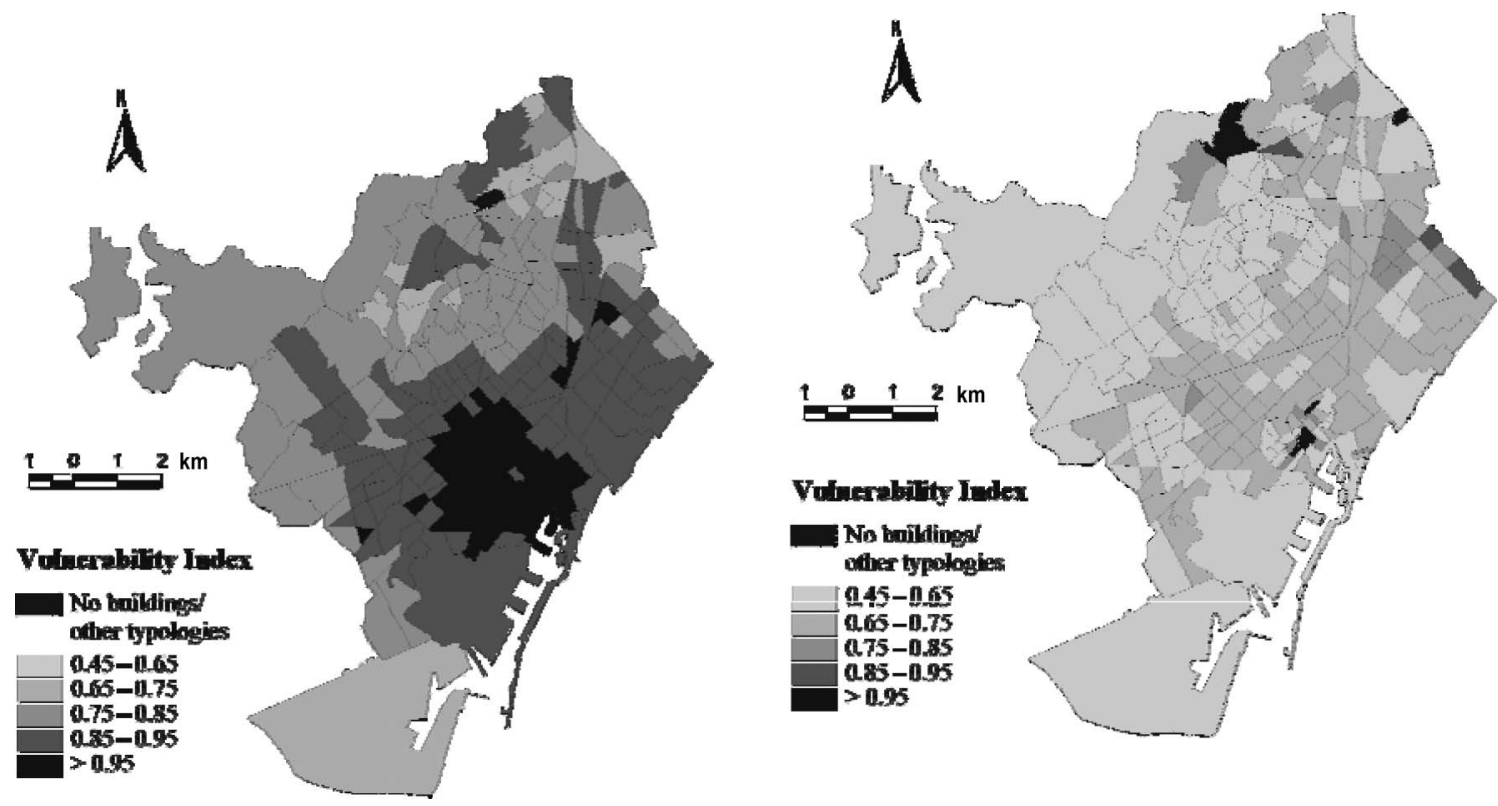

Figure 11. Vulnerability index maps for: (a) unreinforced masonry buildings and (b) reinforced concrete buildings (Barbat et al. 2006a).
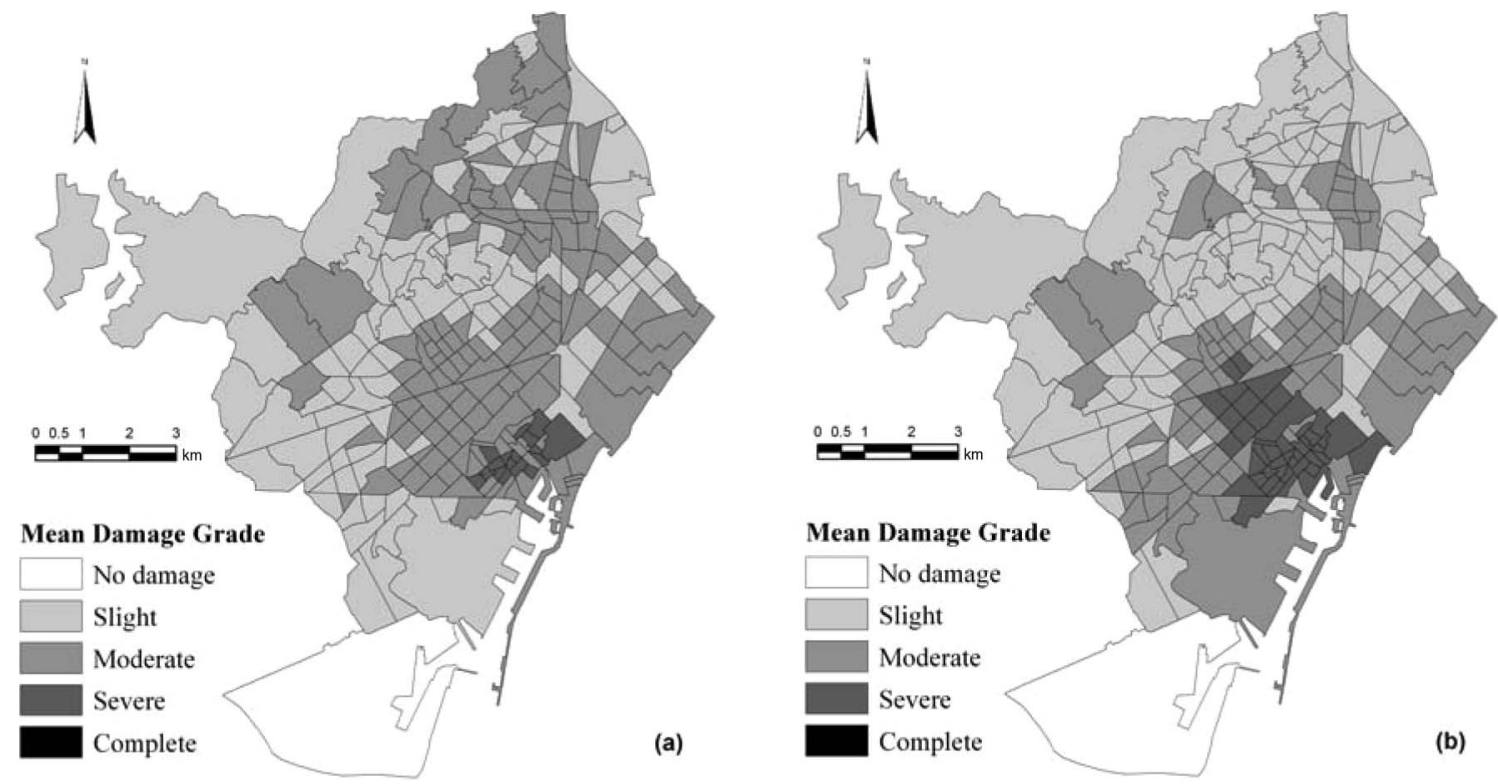

Figure 12. Distribution of the estimated mean damage state using VIM by census zones for: (a) the deterministic and (b) the probabilistic seismic scenario (Lantada et al. 2008).

mechanical models, which are essentially based on the capacity spectrum method (Freeman 1978, 1998, HAZUS 1999). The method permits evaluating the expected seismic performance of structures by comparing, in spectral coordinates, their seismic capacity with the seismic demand, described by acceleration-displacement response spectra (ADRS) adequately reduced in order to take into account inelastic behaviour (Fajfar 2000, 2002).

Risk scenarios were developed for Barcelona by means of a building-by-building simulation, which required the seismic characterisation of 60,653 residential buildings. A simplified building typology matrix with only six models was used, which 
reasonably represents the wide number of buildings of the city. Selected, representative, existing buildings were analysed by using simplified structural analysis models that adequately describe their seismic behaviour. Capacity curves, or pushover curves, have been calculated by means of a nonlinear analysis by loading monotonically the representative structures with a force according to a given load pattern (Mata et al. 2007, 2008). Usually, this load pattern corresponds to the shape of the fundamental mode of vibration. This assumption would be inaccurate for flexible buildings, with a fundamental period higher than $1 \mathrm{~s}$ (ATC-40 1996). The highest expected period of the residential buildings existing in Barcelona is about $1 \mathrm{~s}$, which corresponds to high-rise reinforced concrete buildings. The capacity spectra were developed in their bilinear simplified form, defined by the yielding and ultimate capacity points, for both unreinforced masonry and reinforced concrete buildings. In spite of the limitations of the push-over analysis and of using simplified capacity curves, the procedure, applied with the purpose of calculating seismic risk scenarios for the whole city, provides a reasonably good approximation of the expected damage of the residential buildings of Barcelona (Bonett 2003, Moreno 2006, Lantada 2007).

Detailed structural plans were used to model representative buildings for low-rise (two stories, $5.2 \mathrm{~m}$ tall) mid-rise (five stories, $15.8 \mathrm{~m}$ tall) and high-rise (eight stories, $24.0 \mathrm{~m}$ tall) reinforced concrete buildings. Capacity curves were obtained by performing non-linear static analyses with the two-dimensional version of the computer code RUAUMOKO (Carr 2000), by using advanced constitutive models (Faleiro et al. 2008). Structures were modelled by means of several plane frames connected to each other. The rigid diaphragm effect was considered by constraining the nodes belonging to the same storey.

In a similar way, based on detailed structural plans, three unreinforced masonry buildings of the Eixample district of Barcelona have been modelled. An old building, which is still in use today, located in the Eixample district, was used as a sample to develop masonry building models. The analysed unreinforced masonry models correspond to two stories (low-rise), four stories (mid-rise) and six stories (high-rise) buildings of Barcelona. Other details about the buildings of Barcelona and their modelling can be seen in Barbat et al. (2008). The TreMuri computer program (Galasco et al. 2002) was used to analyse the buildings. This program is a useful tool to study the non-linear in-plane mechanical behaviour of masonry panels and to assess the expected damage for masonry buildings due to earthquakes.

Figures 13 and 14 show capacity spectra plots corresponding to representative buildings that have been analysed. A significant ductility can be observed in Figure 14 for mid-rise and high-rise masonry buildings. This fact should be related to an excessive slenderness of these buildings and also to the failure criterion used in the pushover analysis, which was proposed by Gambarotta and Lagomarsino (1993) and is used by the computer program TreMuri. This model is based on non-linear macro-elements, each one representative for a whole masonry panel, and permits the description, with a limited number of degrees of freedom, the two main masonry failure modes, i.e. bending-rocking and shear-sliding (with friction), starting from mechanical assumptions and damage and plasticity constitutive models (Barbat et al. 1997, Hanganu et al. 2002, Oller and Barbat 2006). The model, one of the few existing tools that is adequate to analyse masonry buildings of the type existing in Barcelona, considers, by means of internal variables, the shear-sliding damage evolution, which controls the strength deterioration (softening) and the stiffness degradation. It can be also seen in Figures 13 and 14

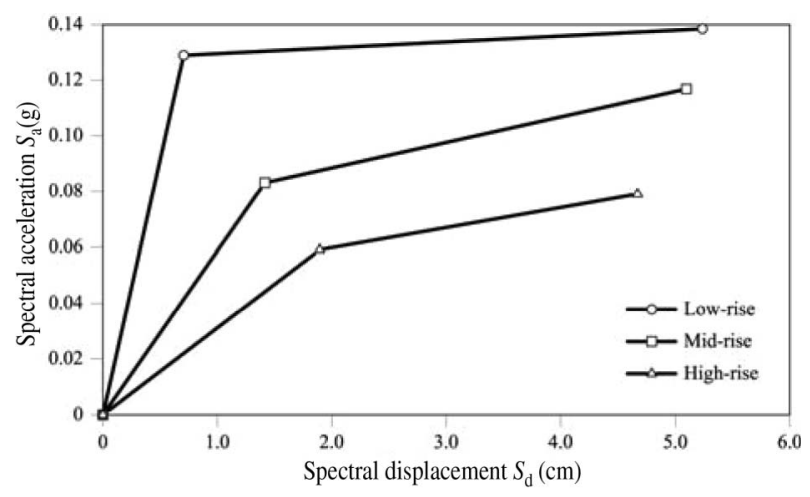

Figure 13. Bilinear capacity spectra for reinforced concrete buildings.

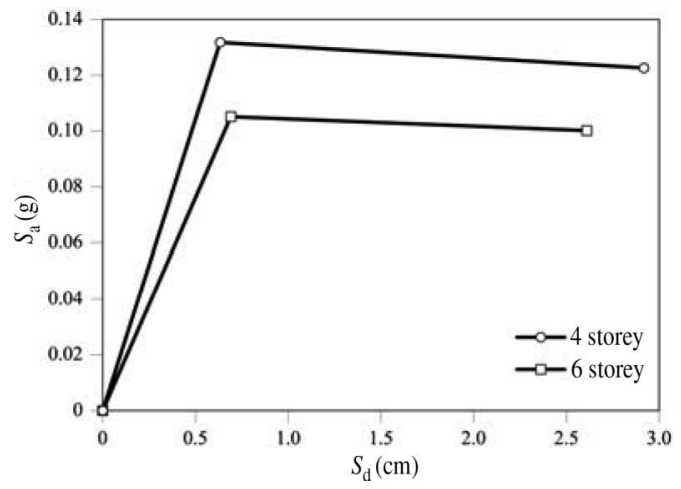

Figure 14. Bilinear capacity spectra for mid-rise and highrise unreinforced masonry buildings. 
how capacity decreases with the height of the building both for masonry and RC buildings. The capacity spectrum for low-rise masonry buildings has not been plotted in Figure 14 because of the high yield and ultimate spectral acceleration values. In fact, this type of building is representative for a number of onefamily houses, mainly located in the residential districts of the city. These buildings practically have no ductility. It has to be pointed out that modern earthquake resistant design codes do not allow the use of high-rise masonry buildings in seismic areas.

\subsection{Fragility curves and damage probability matrices for the buildings of Barcelona}

Fragility curves define the probability that the expected global damage $d$ of a structure equals or exceeds a given damage state, $d_{\mathrm{S}}$, as a function of a parameter quantifying the severity of the seismic action. Let this parameter be the spectral displacement $S_{\mathrm{d}}$. Thus, fragility curves are completely defined by plotting $P\left[d \geq d_{\mathrm{S}}\right]$ versus $S_{\mathrm{d}}$. If it is assumed that fragility curves follow a log-normal probability distribution, they can be completely defined by only two parameters which, in this case, are the mean spectral displacement $\overline{S d}_{\mathrm{ds}}$ and the corresponding standard deviation $\beta_{\mathrm{ds}}$.

Specific fragility curves have been developed for both masonry and reinforced concrete buildings of Barcelona (see Barbat et al. 2006b). Figures 15 and 16 are examples of these curves. Points in these figures correspond to the damage state probabilities and lines are the fitted fragility curves.

It can be seen how reinforced concrete buildings have a better seismic performance than masonry buildings. Fortunately, Barcelona is located in an area of low-medium seismic hazard, but the analyses clearly point out the very high vulnerability of the buildings and, consequently, a significant probability of damage even in the case of a moderate earthquake. It is somewhat surprising that the obtained results show high expected seismic damage for relatively low spectral displacements. They indicate that the

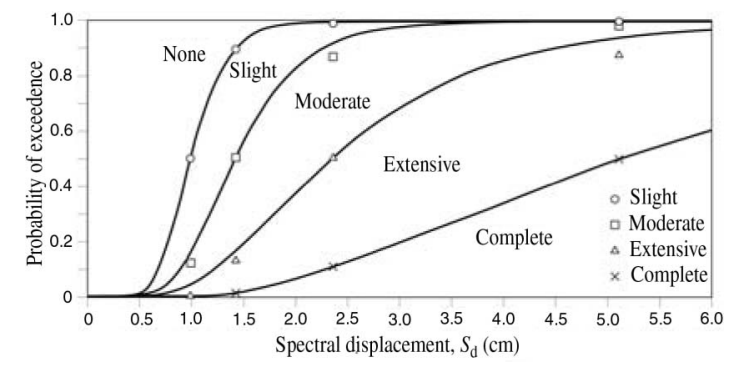

Figure 15. Fragility curves for mid-rise reinforced concrete buildings. reinforced concrete buildings with waffled-slab floors are really weak. This is a reasonable result when taking into account the particular structural type described above.

The process of obtaining damage probability for both masonry buildings and reinforced concrete buildings starts from the $5 \%$ damped elastic spectrum which is, first of all, reduced with the effective damping to obtain the demand spectrum (ATC-40 1996). This is then crossed with the capacity spectrum, an operation that provides the performance point and the expected spectral displacement. Entering then with this value into the corresponding fragility curves, probability damage matrices for the corresponding hazard scenario are obtained. A weighted mean damage state $D S_{\mathrm{m}}$ can be calculated by using the following equation:

$$
D S_{\mathrm{m}}=\sum_{i=0}^{4} D S_{i} P\left[D S_{i}\right]
$$

where $D S_{i}$ takes the values $0,1,2,3$ and 4 for the damage states $i$ considered in the analysis and $P\left[D S_{i}\right]$ are the corresponding probabilities. It can be considered that $D S_{\mathrm{m}}$ is close to the most likely damage state of a structure. Table 3 shows the most probable damage grade as a function of this average damage index that allows plotting seismic damage scenarios by using a single parameter. Of course, alternative maps may plot the spatial distribution of the probability of

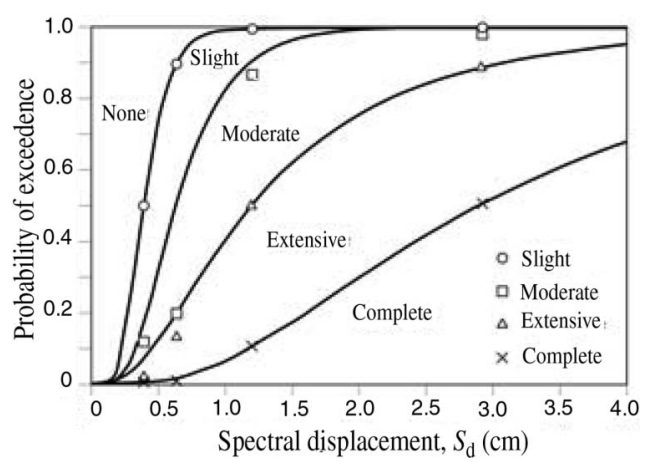

Figure 16. Fragility curves for mid-rise unreinforced masonry buildings.

Table 3. Damage states and mean damage index values.

Mean damage index

intervals

More probable damage state

\begin{tabular}{ll}
\hline $0-0.5$ & No damage \\
$0.5-1.5$ & Slight damage \\
$1.5-2.5$ & Moderate damage \\
$2.5-3.5$ & Extensive damage \\
$3.5-4.0$ & Complete damage \\
\hline
\end{tabular}


occurrence of a specified damage state, that is $P\left[D S_{i}\right]$ for a given damage state $i$.

Table 4 shows the corresponding mean damage grades expected in masonry and reinforced concrete buildings. Starting from these mean damage grades, damage probability matrices can be obtained (Barbat et al. 2008). Using these damage probability matrices, damage scenarios were built.

\subsection{Risk scenarios for Barcelona}

Results for seismic risk scenarios simulated for Barcelona are shown in this section. Spatial convolution between seismic hazard and fragility, through damage probability matrices, allows the estimation of the spatial distribution of expected damage. Although damage is assessed building by building, the damage results are given herein for census zones. The mean damage grade for the entire city is 0.86 for the deterministic scenario, with a standard deviation of 0.71 , while, for the probabilistic case, we obtained a mean damage grade of $1.51 \pm 0.87$, which respectively correspond to slight and moderate damage states according to Table 3 .

Figure 17 shows physical seismic risk scenarios for the deterministic hazard case while Figure 18 shows the scenarios for the probabilistic case. Ciutat Vella is a district downtown of Barcelona that has mainly masonry buildings, which are the oldest buildings of the city. It is expected that Ciutat Vella would be the most damaged district in the case of an earthquake. In the deterministic case, the expected mean damage state for Ciutat Vella and Eixample districts are 1.77 and 1.16 , respectively. In the probabilistic case, these values are 2.49 and 1.9, respectively. Figures $17 \mathrm{~b}$ and $17 \mathrm{c}$ give detailed, building by building, damage scenarios for the districts of Ciutat Vella and Eixample for the deterministic case, and Figure 17a shows a seismic risk scenario for Barcelona, with each cell corresponding to a census zone. Figure 18 shows the same results for the probabilistic scenario. Other supplementary scenarios, such as risk scenarios showing the probability of a given damage level, can be seen in Lantada (2007) and Lantada et al. (2008). For the probabilistic hazard case, Figure 19 shows damage scenarios obtained by using the vulnerability index and the capacity spectrum methods.

\section{Holistic evaluation of the seismic risk}

From a holistic perspective, disaster risk requires a multi-disciplinary evaluation that takes into account not only the expected physical damage, the number and type of casualties or economic losses (direct impact), but also the conditions related to social fragility and lack of resilience conditions, which favour the second-order effects (indirect impact) when a hazard event strike an urban centre (Cardona and Hurtado 2000, Masure 2003, Carreño et al. 2007a).

The total risk index, $R_{\mathrm{T}}$, is a composite index that measures seismic risk from an integrated and comprehensive perspective and guides decision-making when identifying the main multi-disciplinary factors of vulnerability to be reduced or intervened. The first step of the method is the evaluation of the potential physical damage as a result of the convolution of seismic hazard and physical vulnerability of buildings and infrastructure. Subsequently, a set of social context conditions that aggravate the physical effects are also considered. According to this procedure, a physical risk index is obtained for each unit of analysis, starting from existing loss scenarios; the total risk index is obtained by factoring the former index by an impact factor using an aggravating coefficient based on variables associated with the socio-economic conditions of each unit of analysis. This idea is expressed by the equation known in the field of disaster risk indicators as Moncho's equation, which

Table 4. Mean damage grades, $D S_{\mathrm{m}}$ for masonry and reinforced concrete buildings in Barcelona, obtained by means of the capacity spectrum based method for deterministic and probabilistic scenarios.

\begin{tabular}{|c|c|c|c|c|c|c|c|}
\hline & \multirow[b]{2}{*}{ Zone } & \multicolumn{3}{|c|}{ Unreinforced masonry } & \multicolumn{3}{|c|}{ Reinforced concrete } \\
\hline & & $\begin{array}{l}\text { Low-rise } \\
\text { (1-2 floors) }\end{array}$ & $\begin{array}{c}\text { Mid-rise } \\
\text { (3-5 floors) }\end{array}$ & $\begin{array}{l}\text { High-rise } \\
\text { ( } \geq 6 \text { floors) }\end{array}$ & $\begin{array}{l}\text { Low-rise } \\
\text { (1-3 floors) }\end{array}$ & $\begin{array}{c}\text { Mid-rise } \\
\text { (4-7 floors) }\end{array}$ & $\begin{array}{c}\text { High-rise } \\
\text { ( } \geq 8 \text { floors) }\end{array}$ \\
\hline \multirow{4}{*}{$\begin{array}{l}\text { Deterministic } \\
\text { scenario }\end{array}$} & I & 0.07 & 2.34 & 2.40 & 1.96 & 1.23 & 0.82 \\
\hline & II & 0.35 & 1.60 & 1.56 & 1.33 & 0.44 & 0.30 \\
\hline & III & 0.11 & 1.25 & 1.16 & 0.89 & 0.21 & 0.10 \\
\hline & $\mathrm{R}$ & 0.00 & 0.64 & 0.57 & 0.34 & 0.11 & 0.11 \\
\hline \multirow{4}{*}{$\begin{array}{c}\text { Probabilistic } \\
\text { scenario }\end{array}$} & I & 0.50 & 2.81 & 2.98 & 2.05 & 1.51 & 1.19 \\
\hline & II & 1.07 & 2.31 & 2.44 & 1.61 & 0.83 & 0.68 \\
\hline & III & 0.81 & 2.01 & 2.15 & 1.30 & 0.53 & 0.44 \\
\hline & $\mathrm{R}$ & 0.03 & 1.60 & 0.50 & 0.78 & 0.44 & 0.52 \\
\hline
\end{tabular}



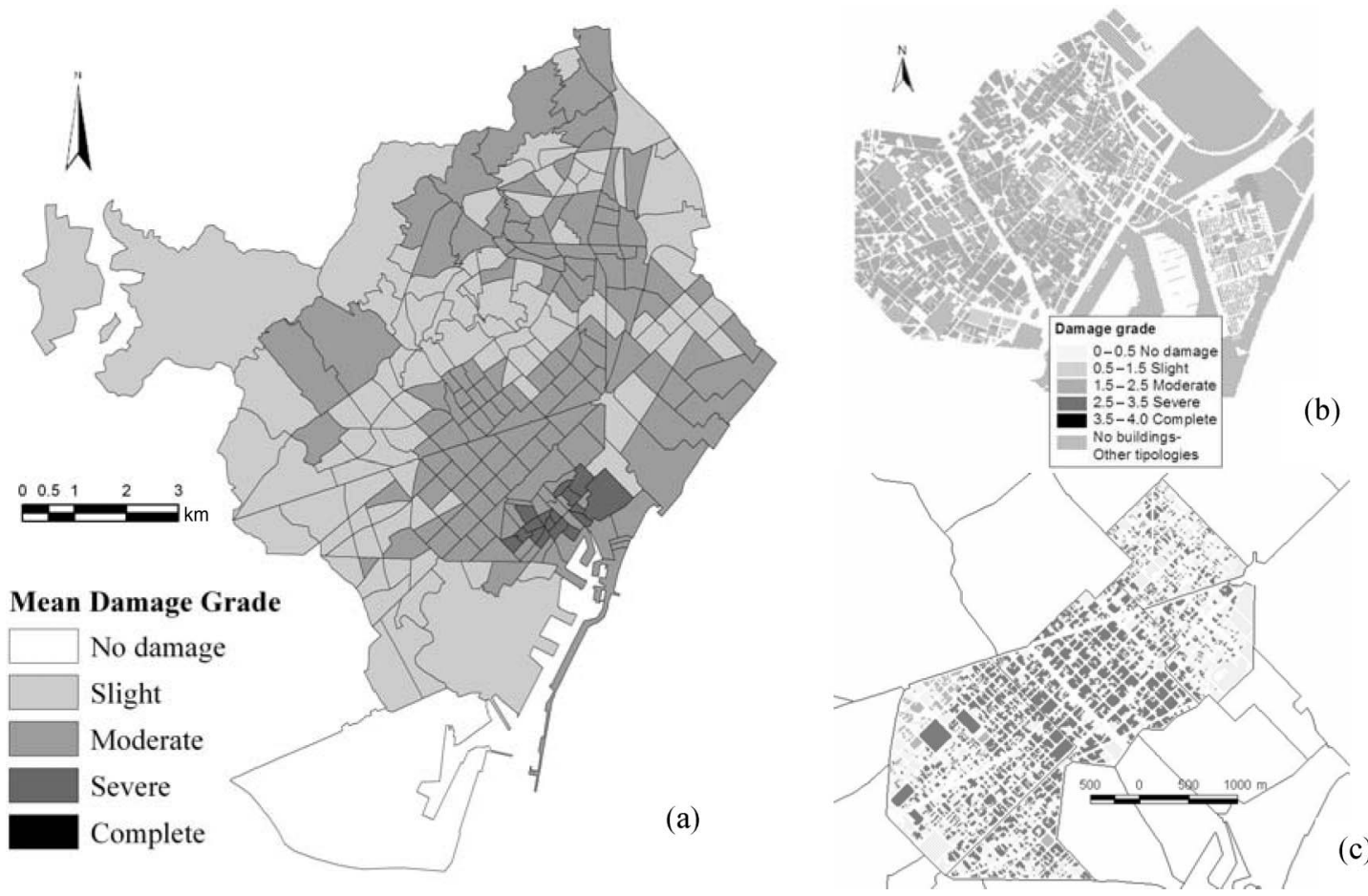

Figure 17. Damage scenario corresponding to the deterministic hazard scenario: (a) Barcelona, (b) Ciutat Vella district and (c) Eixample district.
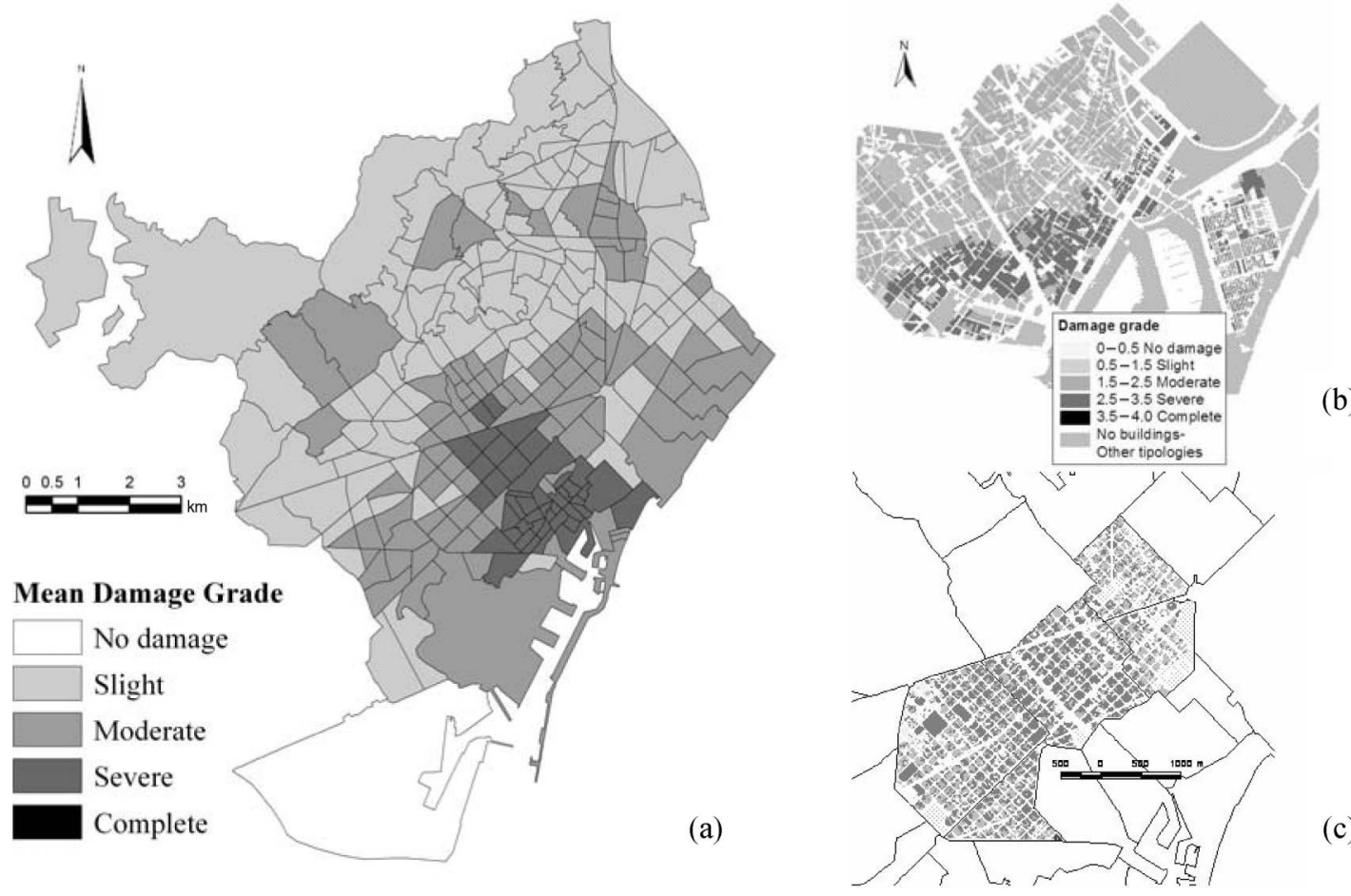

Figure 18. Damage scenario corresponding to the probabilistic hazard scenario: (a) Barcelona, (b) Ciutat Vella district and (c) Eixample district. 

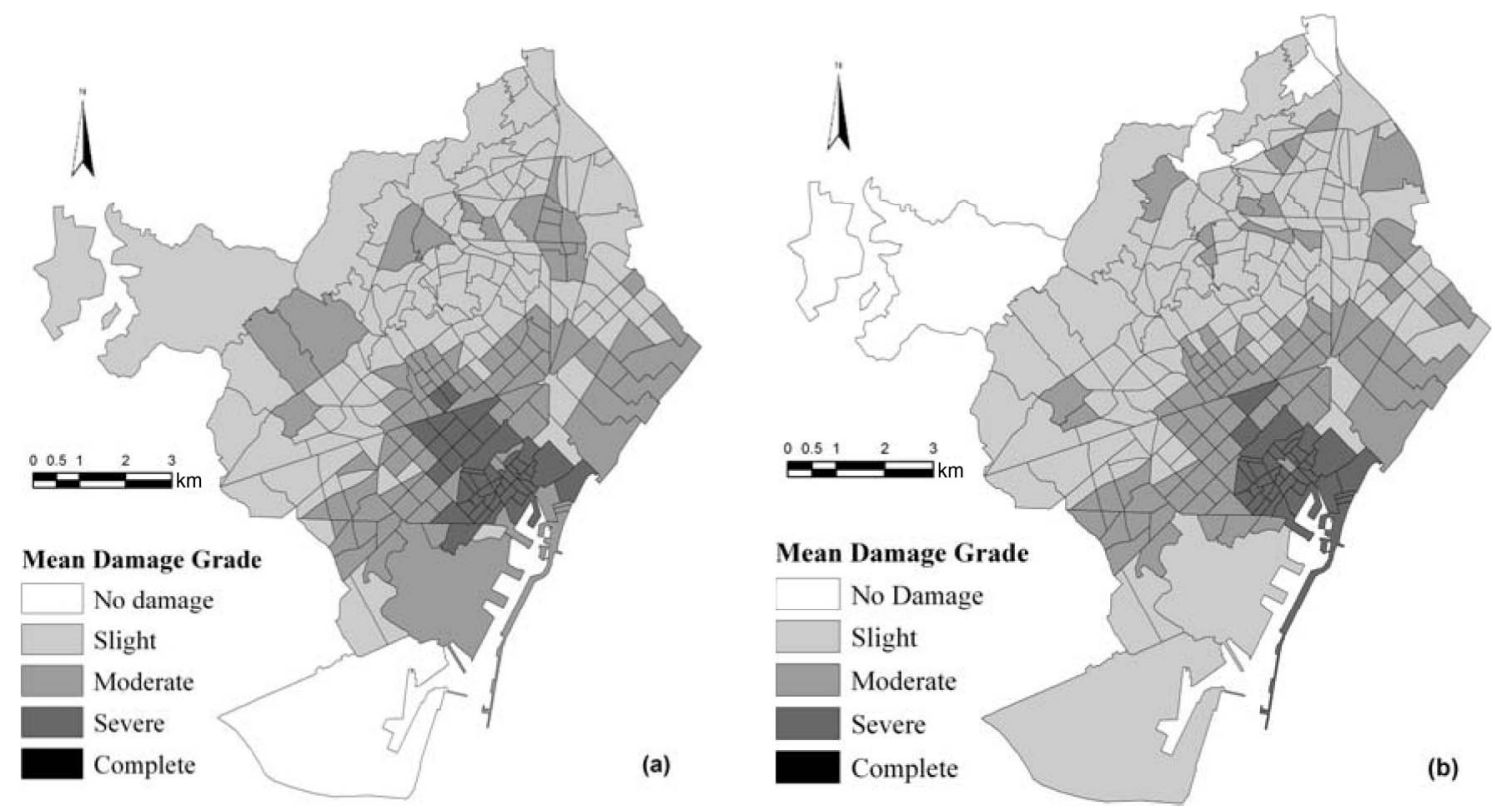

Figure 19. Damage scenarios in the probabilistic hazard using: (a) the vulnerability index method and (b) the capacity spectrum method.

allows the calculation of the $R_{\mathrm{T}}$ for each unit of analysis as:

$$
R_{\mathrm{T}}=R_{\mathrm{F}}(1+F),
$$

where $R_{\mathrm{T}}$ is the total risk index; $R_{\mathrm{F}}$ is the physical risk index and the indirect effects given by an impact factor $(1+F)$, based on an aggravating coefficient; and $F$ is the aggravating coefficient. In the case of seismic risk, the total risk index, $R_{\mathrm{T}}$, is called the urban seismic risk index (USRi).

The holistic evaluation of risk is performed using a set of input variable denominated descriptors. They reflect the physical risk and the aggravating conditions that contribute to the potential impact. Those descriptors are obtained from the loss scenarios and from socio-economic and coping capacity information of the exposed context (Carreño et al. 2005). The physical risk index, $R_{\mathrm{F}}$, depends on the weighted sum of a set of component factors:

$$
R_{\mathrm{F}}=\sum_{i=1}^{p} F_{\mathrm{RF} i} w_{\mathrm{RF} i}
$$

where $p$ is the total number of descriptors of the physical risk index; $F_{\mathrm{RF} i}$ are the component factors; and $w_{\mathrm{RF} i}$ are their weights. The factors of physical risk, $F_{\mathrm{RF} i}$, are based on the gross values of physical risk descriptors such as the number of deaths, injuries, destroyed areas, etc. using transformation functions.
These functions standardise the gross values of the descriptors transforming them in commensurable factors.

The coefficient $F$ is evaluated in the same way. It depends on the weighted sum of a set of aggravating factors related to the socio-economic fragility, $F_{\mathrm{FS} i}$, and the lack of resilience of the exposed context, $F_{\mathrm{FR} j}$

$$
F=\sum_{i=1}^{m} F_{\mathrm{FS} i} w_{\mathrm{FS} i}+\sum_{j=1}^{n} F_{\mathrm{FR} j} w_{\mathrm{FR} j}
$$

where $w_{\mathrm{FS} i}$ and $w_{\mathrm{FR} j}$ are the weights or influences of each $i$ and $j$ factor and $m$ and $n$ are the total number of descriptors for social fragility and lack of resilience, respectively. The aggravating factors $F_{\mathrm{FS} i}$ and $F_{\mathrm{FR} j}$ are calculated using the transformation functions. Figure 20 shows the process of calculation of the total risk index for the units of analysis that could be districts, municipalities, communes or localities. A detailed description of the method can be seen in Carreño et al. (2007a), where the units of each descriptor are also given.

Table 5 shows the values of the weights used in the evaluation performed for Barcelona. The weights represent the relative importance of each physical risk factor or aggravating coefficient. They are calculated by means of the analytic hierarchy process (AHP), which is used to derive ratio scales from both discrete and continuous paired comparisons (Saaty 


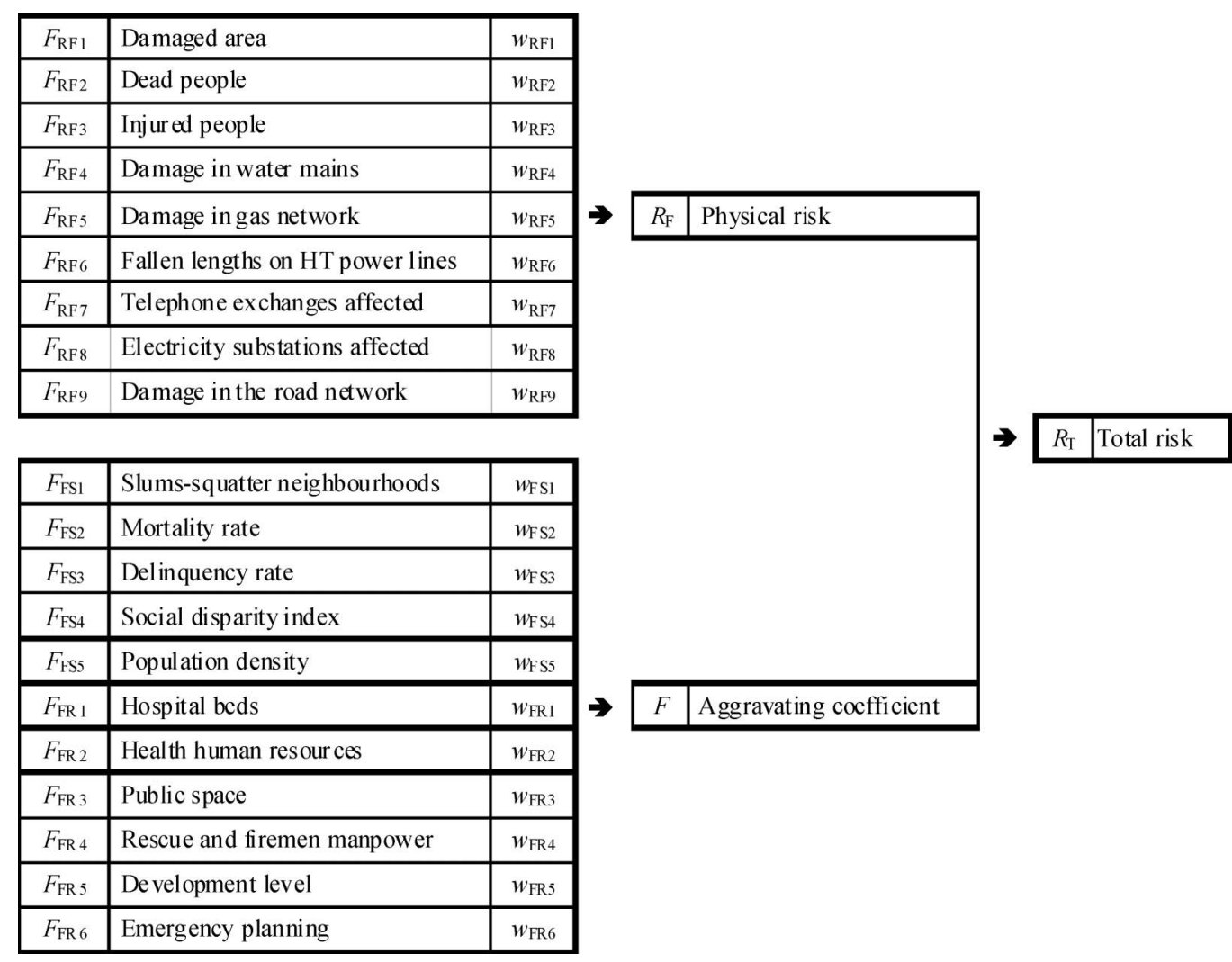

Figure 20. Factors of physical risk, social fragility and lack of resilience and their weights.

Table 5. Weights of the physical risk and aggravating factors used for the holistic risk evaluation in Barcelona.

\begin{tabular}{|c|c|c|c|c|c|}
\hline \multicolumn{3}{|c|}{ Physical risk } & \multicolumn{3}{|c|}{ Aggravating factors } \\
\hline & Factor & Weight & & Factor & Weight \\
\hline $\begin{array}{l}F_{\mathrm{RF} 1} \\
F_{\mathrm{RF} 2} \\
F_{\mathrm{RF} 3} \\
F_{\mathrm{RF} 4} \\
F_{\mathrm{RF} 5} \\
F_{\mathrm{RF} 6} \\
F_{\mathrm{RF} 7} \\
F_{\mathrm{RF} 8} \\
F_{\mathrm{RF} 9}\end{array}$ & $\begin{array}{l}\text { Damaged area } \\
\text { Dead people } \\
\text { Injured people } \\
\text { Damage in water mains } \\
\text { Damage in gas network } \\
\text { Fallen lengths on power lines } \\
\text { Telephone exchanges affected } \\
\text { Electricity substations affected } \\
\text { Damage in the road network }\end{array}$ & $\begin{array}{l}0.28 \\
0.09 \\
0.09 \\
0.17 \\
0.10 \\
0.10 \\
0.04 \\
0.04 \\
0.10\end{array}$ & $\begin{array}{l}F_{\mathrm{FS} 1} \\
F_{\mathrm{FS} 2} \\
F_{\mathrm{FS} 3} \\
F_{\mathrm{FS} 4} \\
F_{\mathrm{FS} 5} \\
F_{\mathrm{FR} 1} \\
F_{\mathrm{FR} 2} \\
F_{\mathrm{FR} 3} \\
F_{\mathrm{FR} 4} \\
F_{\mathrm{FR} 5} \\
F_{\mathrm{FR} 6}\end{array}$ & $\begin{array}{l}\text { Slums-squatter neighbourhoods } \\
\text { Mortality rate } \\
\text { Delinquency rate } \\
\text { Social disparity index } \\
\text { Population density } \\
\text { Hospital beds } \\
\text { Health human resources } \\
\text { Public space } \\
\text { Rescue and firemen manpower } \\
\text { Development level } \\
\text { Emergency planning }\end{array}$ & $\begin{array}{l}0.18 \\
0.04 \\
0.04 \\
0.18 \\
0.18 \\
0.06 \\
0.06 \\
0.04 \\
0.03 \\
0.09 \\
0.09\end{array}$ \\
\hline
\end{tabular}

2001). Expert opinion was used in the weights estimation.

In order to develop the transformation functions, sigmoid functions were used in most cases. Once decided the shape of the functions, their maximum and minimum values (corresponding to 1 or 0 values of each factor) were fixed using existing information about past disasters, as well as the opinion of American and European experts. The transformation functions describe the intensity of the risk for each descriptor. Figure 21 shows two transformation function examples. Figure 21a corresponds to the mortality rate, defined as the number of deaths by natural causes for each 10,000 inhabitants; it suggests that the aggravation for this factor is minimal if it takes a value smaller than 50 deaths for each 10,000 inhabitants and that it is maximal if the value is bigger than 4000 deaths for each 10,000 inhabitants. 
Figure $21 \mathrm{~b}$ corresponds to the damaged built area; the transformation function defines a minimum risk of 0 when the built area is undamaged and a maximum risk of 1 if a potential damage of $20 \%$ of the built area occurs.

Figure 22 shows the results for the physical risk index and the USRi calculated for the probabilistic seismic scenario (RISK-UE 2004) for the 248 small zones. From these results, average values can be calculated for the physical risk index and the USRi for districts of Barcelona. Figure 23 shows the results for the aggravating coefficient defined by Equation 2 . Table 6 shows the comparison between results for both deterministic and probabilistic scenarios.
A sensitivity analysis has been performed to study the robustness of the model. A Monte Carlo-based simulation was performed in order to analyse the variation in the values of the USRi. This index can be influenced by uncertainties in the source data or in the weights and transformation functions. These uncertainties can have their origin in the subjectivity of the stakeholders or in their plurality of perspectives.

The application of the Monte Carlo simulation method (Hurtado and Barbat 1998) allows the analysis of uncertainty propagation and the determination of how random variation of data affects the sensitivity, performance or reliability of the model. The values of the USRi for each territorial unit were calculated 5000
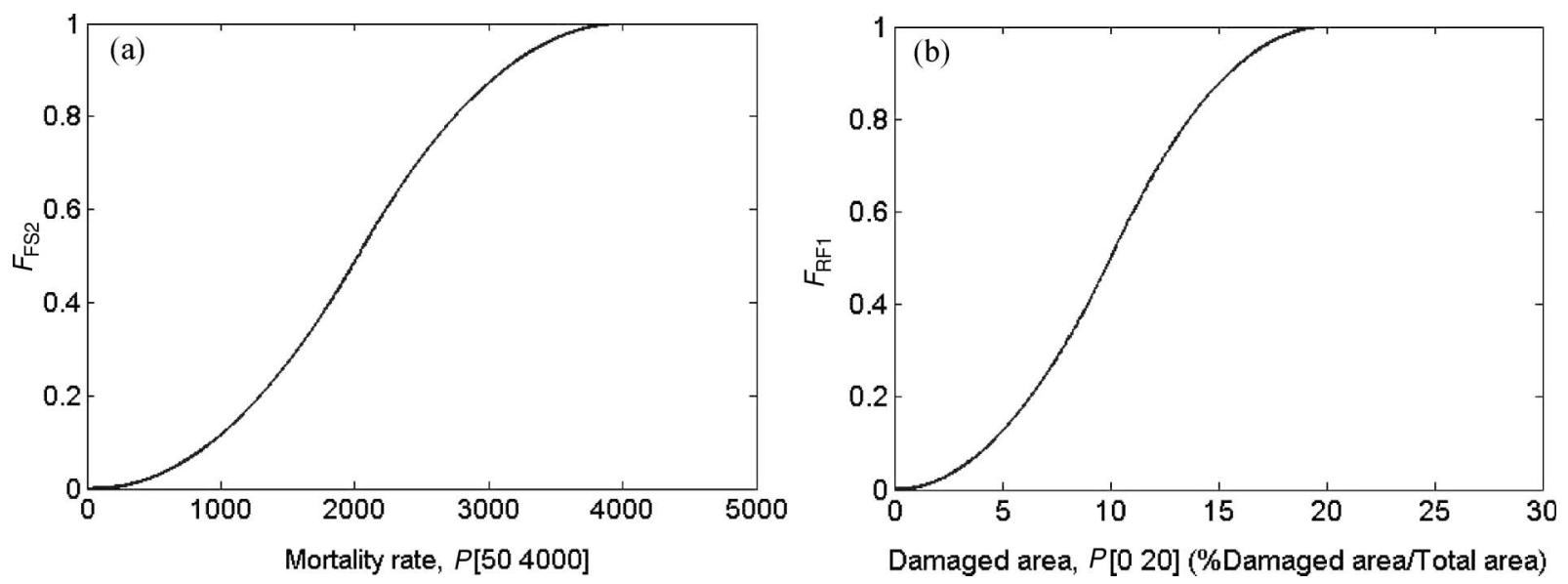

Figure 21. Examples of transformation functions: (a) mortality rate and (b) damaged area.

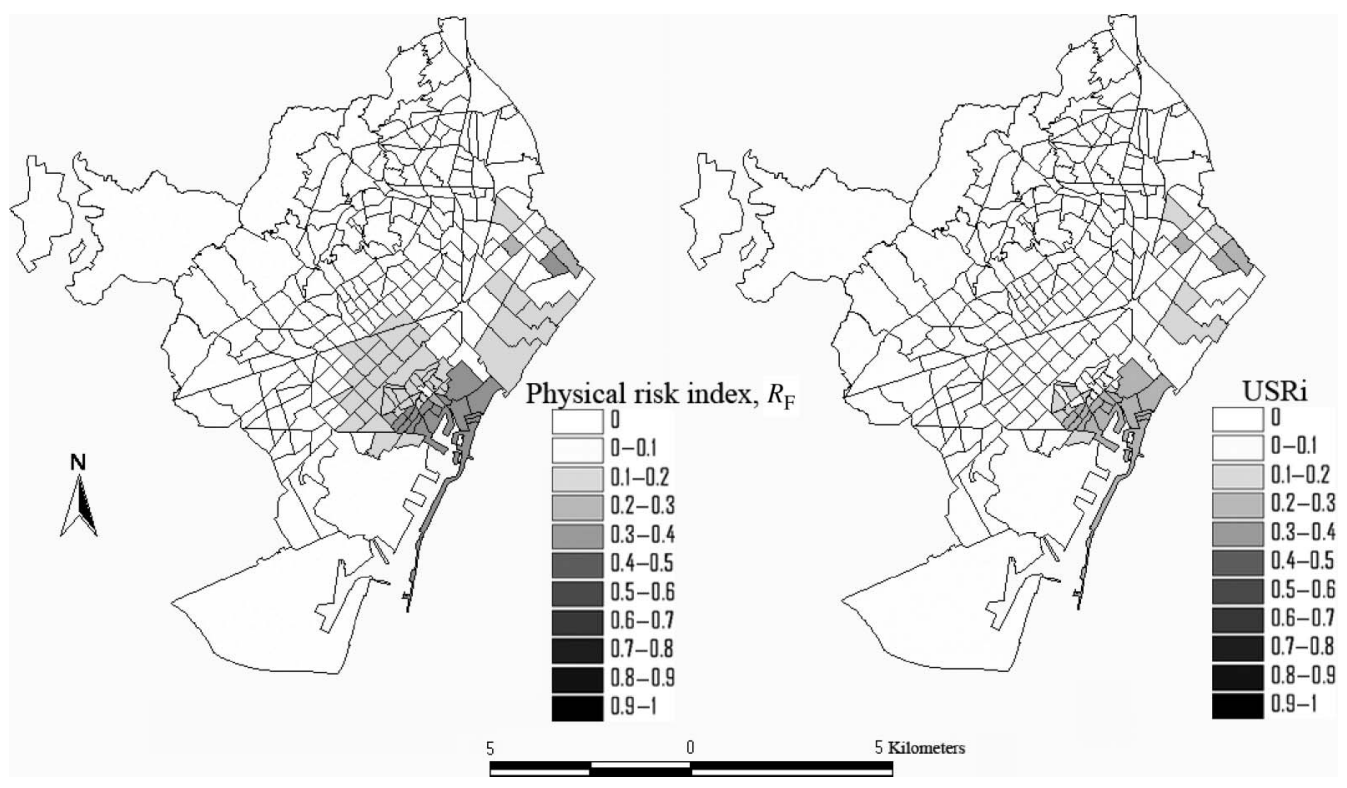

Figure 22. (a) Physical risk index $\left(R_{\mathrm{F}}\right)$ and (b) USRi for probabilistic seismic scenarios. 


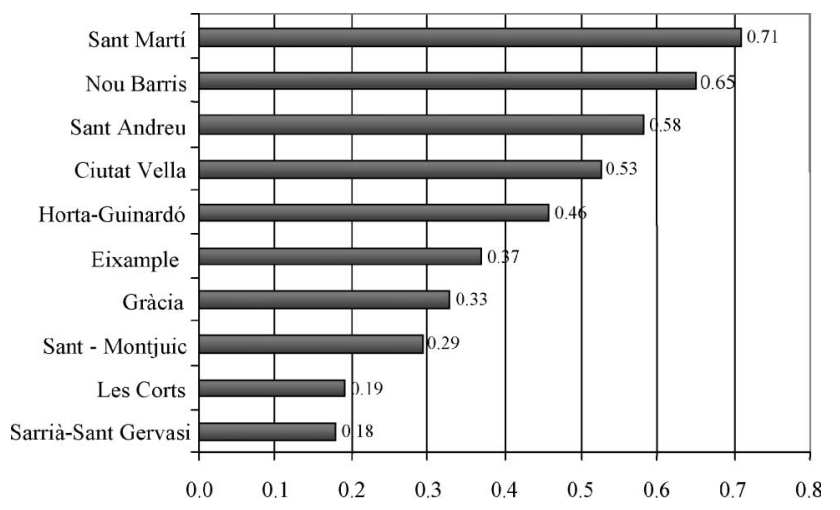

Figure 23. Aggravating coefficients for the districts of Barcelona.

Table 6. Comparison between average values for Barcelona.

\begin{tabular}{|c|c|c|}
\hline Index & $\begin{array}{l}\text { Deterministic } \\
\text { scenario }\end{array}$ & $\begin{array}{l}\text { Probabilistic } \\
\text { scenario }\end{array}$ \\
\hline $\begin{array}{l}\text { Physical risk, } R_{\mathrm{F}} \\
\text { Aggravating coefficient, } F\end{array}$ & 0.03450 & 0.0759 \\
\hline $\begin{array}{l}\text { Urban seismic } \\
\text { risk index, USRi }\end{array}$ & 0.0501 & 0.1102 \\
\hline
\end{tabular}

times, using random sets of input data, transformation functions and weights; each value has been sampled within a feasible range of variability, according to the experience available in different places of the world and the criteria of expert stakeholders. Once the results were calculated using Monte Carlo simulations, variability graphs were built to compare the stochastic results of the USRi with the results obtained using the deterministic features of the methodology. Figures 24 and 25 illustrate minimum, maximum and mean values of the USRi and the bars represent the deterministic values obtained for each territorial unit. It can be seen that, for the considered variability of the stochastic weights and stochastic input data, the variability of results is not significant for the ranking change of the territorial units. The same simulation procedure was applied to study the effect of the stochastic transformation functions and the variation of all parameters on the USRi.

Table 7 shows that the results obtained by means of simulation are very similar to the results obtained using deterministic values of input data, weights and the transformation functions (TF) of the method previously described and applied to Barcelona. The overall results show that the districts of the city vary slightly in their rankings. Some units fluctuate by one or two positions.

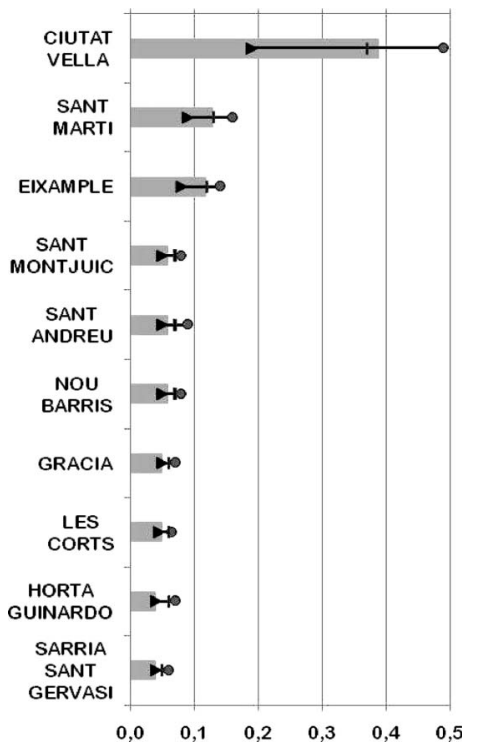

Figure 24. USRi for deterministic and stochastic weights (minimum $(\bullet)$, maximum $(\bullet)$ and mean $(\mid)$ ).

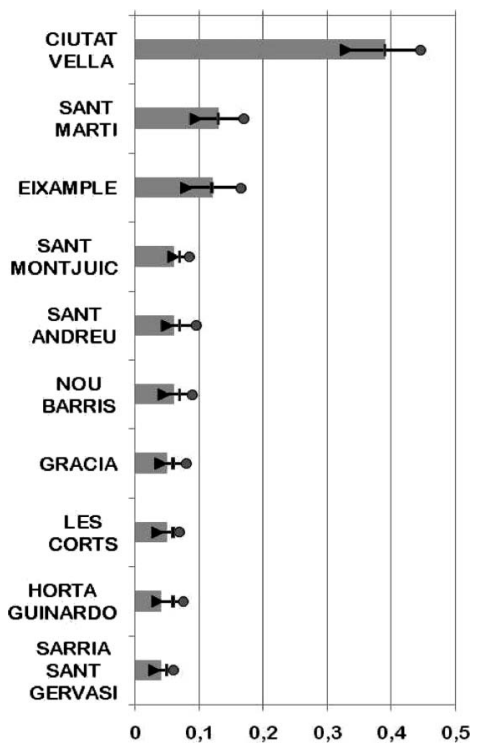

Figure 25. USRi for deterministic and stochastic input data (minimum $(\triangleright)$, maximum $(\bullet)$ and mean $(\mid)$ ).

Classification by ranges of risk has special interest, as it is more relevant to take into account the level of risk where a territorial unit is located than its final numerical value for risk management implications.

According to the comparison of the results of sensitivity analysis, based on Monte Carlo simulations, and the results obtained by the holistic seismic risk evaluation described here, it is possible to conclude that the methodology is robust. It is not very sensitive 
Structure and Infrastructure Engineering

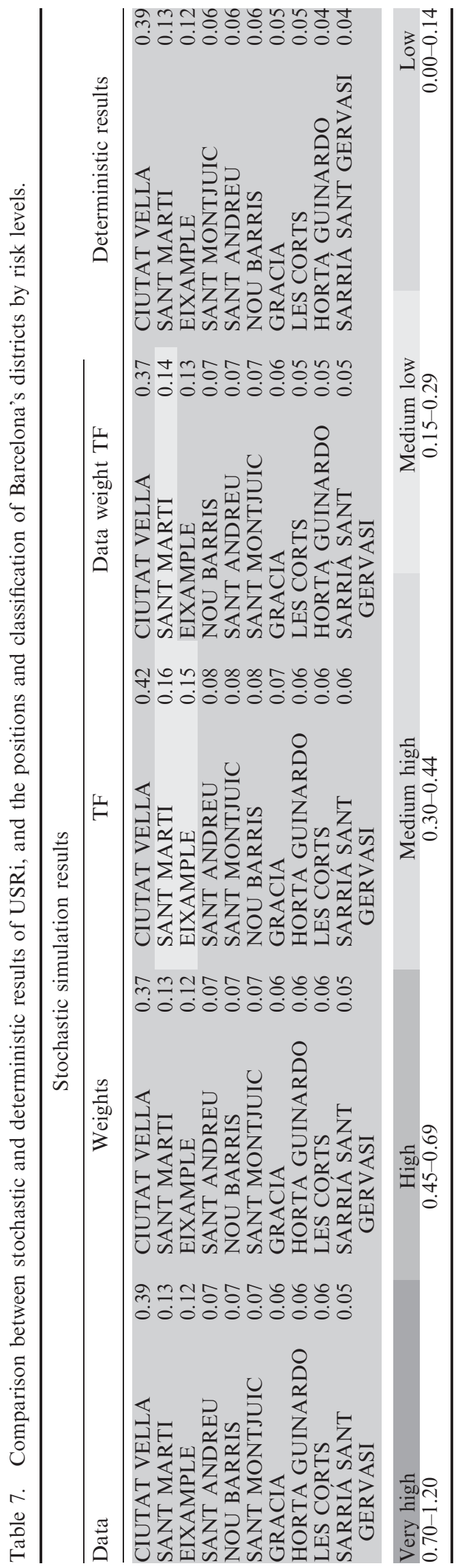

to slight variations in the input data and small changes in the modelling parameters, such as weights and transformation functions. The results do not present important or extreme changes. If the range of variation of data and parameters is reasonable, as is in the case of seismic risk, in general, the results of the model will be stable and reliable.

\section{Conclusions}

A review of relevant existing methods for urban seismic risk assessment has been performed in the article. The city of Barcelona has been used as a pilot urban area and studied. The most important results that have been obtained are compared and discussed. In spite of the differences, both the vulnerability index and capacity spectrum methods show a reasonably good correlation with the main features of the built-up environment of Barcelona. In both cases, the results show that in a city such as Barcelona, located in a low to moderate seismic hazard region, in which no attention has been paid in the past to the seismic design of its buildings, high seismic vulnerability and a considerable risk are expected.

Another interesting feature of the described methodologies is their ability to draw the main characteristics of the built-up environment of the city, underlying the radial pattern of the damage. Downtown, where buildings are older, population density is higher and economy is more active, we find the highest vulnerability. The methods described here may be easily adapted to outline risk evaluations for other cities. Probably most of the vulnerability indices adopted for Barcelona may be slightly modified and directly used for obtaining risk scenarios for other cities of Spain and, in particular, for those situated in the Mediterranean region.

Other outcomes of the study refer to the practical seismic vulnerability characterisations of the buildings of Barcelona. Reliable capacity curves have been obtained, which show a wide vulnerability range for both the masonry and the reinforced concrete buildings. Capacity and fragility curves have been developed for more than $95 \%$ of the residential building stock of the city, which has been well represented by six building classes. Credible hazard scenarios in response spectrum format have been used for the studied urban area. Significant damage has been obtained for midrise and high-rise masonry buildings, mainly due to the slenderness of these buildings. Reinforced concrete buildings also show low seismic capacity leading to significant expected damage, which can be attributed mainly to the column and slab structural type. Damage probability matrices have been obtained for the four seismic areas of the city, allowing the development of 
representative risk scenarios, which are based on a complete and highly reliable database for the buildings of the city. Seismic risk scenarios have been developed based on a building-by-building analysis. These physical damage scenarios have been mapped according to different territorial or political areas of the city such as districts, neighbourhoods and census zones. They constitute excellent information sources and tools for risk reduction and transfer preparedness, emergency response planning and post-disaster recovery.

Finally, a holistic evaluation of seismic risk has been performed by means of a methodology that proved to be robust, and which facilitates the integrated risk management by the different stakeholders involved in risk reduction decision-making. Once the results have been obtained for each district, it is easy to identify the most relevant aspects of the urban seismic risk index (USRi). The results can be used in order to establish mitigation priorities, as well as prevention and planning actions, allowing the modification of those conditions (sub-indicators) that have a greater influence on risk. This technique allows the comparison of risk among different cities or megacities because the USRi provides a common 'rule' of measurement to compare and benchmark the results. It is a comprehensive technique where the underlying concept is one of controlling risk, rather than obtaining a precise evaluation of it. The goal is not only to reveal a truth, but also to provide information and analyses that can improve decisions.

\section{Acknowledgements}

This work has been partially sponsored by the Spanish Ministry of Education and Science and with FEDER funds (projects: CGL2004-22325-E, CGL-2005-04541-C03-02/ BTE, HABITAT 2030-PSS-380000-2005-14 and SEDUREC-CSD2006-00060) and by the European Commission (RISK-UE project EVK4-CT-2000-00014).

\section{References}

Ambraseys, N.N., Simpson, K.A., and Bommer, J.J., 1996. Prediction of horizontal response spectra in Europe. Earthquake Engineering and Structural Dynamics, 25, 375-400.

Anagnos, T., Rojahn, C., and Kiremidjian, A., 1995. NCEER-ATC joint study on fragility of buildings. Buffalo, NewYork: National Center for Earthquake Engineering Research, report NCEER-95-0003.

Angeletti, P., Bellina, A., Grandori, E., Moretti, A., and Petrini, V., 1988. Comparison between vulnerability assessment and damage index, some results. In: Proceedings of 9th world conference on earthquake engineering, Tokyo, 7, 181-186.

Applied Technology Council (ATC-13), 1985. Earthquake damage evaluation data for California. Redwood City, CA: ATC.
Applied Technology Council (ATC-40), 1996. Seismic evaluation and retrofit of concrete buildings. Redwood City, CA: Seismic Safety Commission, ATC, report SSC 96-01, volume 1.

Barbat, A.H., Lagomarsino, S., and Pujades, L.G., 2006a. Vulnerability assessment of dwelling buildings. In: C. Sousa, A. Roca, and X. Goula, eds. Assessing and managing earthquake risk. Dordrecht, The Netherlands: Springer, 115-134.

Barbat, A.H., Mena, U., and Yepez, F., 1998. Evaluación probabilista del riesgo sísmico en zonas urbanas. Revista Internacional de Métodos Numéricos para Cálculo y Diseño en Ingeniería, 14, 247-268.

Barbat, A.H., Pujades, L.G., and Lantada, N., 2006 b. Performance of buildings under earthquake in Barcelona, Spain. Computer-Aided Civil and Infrastructure Engineering, 21, 573-593.

Barbat, A.H., Pujades, L.G., and Lantada, N., 2008. Seismic damage evaluation in urban areas using the capacity spectrum method: application to Barcelona. Soil Dynamics and Earthquake Engineering, 28 (10-11), 851-865.

Barbat, A.H., Yepez Moya, F., and Canas, J.A., 1996. Damage scenarios simulation for seismic risk assessment in urban zones. Earthquake Spectra, 12 (3), 371-394.

Barbat, A.H., Oller, S., Oñate, E., and Hanganu, A., 1997. Viscous damage model for Timoshenko beam structures. International Journal of Solids and Structures, 34 (30), 3953-3976.

Benedetti, D. and Petrini, V., 1984. Sulla vulnerabilità sismica di edifici in muratura i proposte di un metodo di valutazione. L'industria delle Construzioni, 149, 66-74.

Bonett, R.L., 2003. Vulnerabilidad y riesgo sísmico de edificios. Aplicación a entornos urbanos en zonas de amenaza alta y moderada. Thesis (PhD). Universidad Politécnica de Cataluña, Barcelona, Spain.

Cardona, O.D., 2001. Estimación holística del riesgo sísmico utilizando sistemas dinámicos complejos. Thesis (PhD). Universidad Politécnica de Cataluña, Barcelona, Spain.

Cardona, O.D., 2004. The need for rethinking the concepts of vulnerability and risk from a holistic perspective: a necessary review and criticism for effective risk management. In: G. Bankoff, G. Frerks, and D. Hilhorst, eds. Mapping vulnerability: disasters, development and people. London, UK: Earthscan Publishers, 37-51.

Cardona, O.D. and Hurtado, J.E., 2000. Holistic seismic risk estimation of a metropolitan center. In: Proceedings of 12th world conference of earthquake engineering, Auckland, New Zealand.

Carr, A., 2000. Inelastic dynamic analysis program: $R U A U$ $M O K O$ and post-processor for RUAUMOKO. Department of Civil Engineering, University of Canterbury.

Carreño, M.L., 2006. Técnicas innovadoras para la evaluación del riesgo sísmico y su gestión en centros urbanos: acciones ex ante. Thesis (PhD). Universidad Politécnica de Cataluña, Barcelona, Spain.

Carreño, M.L., Cardona, O.D., and Barbat, A.H., 2005. System of indicators for risk evaluation (in Spanish). Monographs of Earthquake Engineering, IS-52. Barcelona, Spain: International Center for Numerical Methods in Engineering (CIMNE).

Carreño, M.L., Cardona, O.D., and Barbat, A.H., 2007a. Urban seismic risk evaluation: a holistic approach. Natural Hazards, 40, 137-142.

Carreño, M.L., Cardona, O.D., and Barbat, A.H., 2007b. Disaster risk management performance index. Natural Hazards, 41, 1-20. 
Cid, J., 1998. Zonificación sísmica de la ciudad de Barcelona basada en métodos de simulación numérica de efectos locales. Thesis (PhD). Universidad Politécnica de Cataluña, Barcelona, Spain.

Cid, J., Susagna, T., Goula, X., Chavarria, L., Figueras, S., Fleta, J., Casas, A., and Roca, A., 2001. Seismic zonation of Barcelona based on numerical simulation of site effects. Pure and Applied Geophysics, 158, 2559-2577.

Comité Européen de Normalisation (CEN), 2004. Eurocode 8: design of structures for earthquake resistance. Part 1: General rules, seismic actions and rules for buildings. Brussels: CEN.

Departament d'Estadística, 2002. Anuari estadístic de la ciutat de Barcelona 2002. Barcelona, Spain: Departament d'Estadística, Ajuntament de Barcelona.

Egozcue, J.J., Barbat, A.H., Canas, J.A., Miquel, J., and Banda, E., 1991. A method to estimate intensity occurrence probabilities in low seismic activity regions. Earthquake Engineering and Structural Dynamics, 20, 43-60.

Fajfar, P., 2000. A non linear analysis method for performance-based seismic design. Earthquake Spectra, 16 (3), 573-5924.

Fajfar, P., 2002. Structural analysis in earthquake engineering - a breakthrough of simplified non-linear methods. In: 12th European conference on earthquake engineering, London, UK.

Faleiro, J., Oller, S., and Barbat, A.H., 2008. Plastic-damage seismic model for reinforced concrete frames. Computers and Structures, 86, 581-597.

Freeman, S.A., 1978. Prediction of response of concrete buildings to severe earthquake motion. In: Proceedings of Douglas McHenry international symposium on concrete and concrete structures, publication SP-55, American Concrete Institute, Detroit, Michigan, USA.

Freeman, S.A., 1998. The capacity spectrum method. In: Proceedings of the 11th European conference on earthquake engineering, Paris, France.

Galasco, A., Lagomarsino, S., and Penna, A., 2002. TREMURI program: seismic analysis of $3 D$ masonry buildings. Italy: University of Genoa.

Gambarotta, L. and Lagomarsino, S., 1993. A microcrack damage model for brittle materials. International Journal of Solids and Structures, 30, 177-198.

Grünthal, G., ed. 1998. European macroseismic scale 1998. (volume 15). Luxemburg: Centre Européen de Géodynamique et Séismologie, Cahiers du Centre Européen de Géodynamique et de Séismologie.

Hanganu, A., Oñate, E., and Barbat, A.H., 2002. A finite element methodology for local/global damage evaluation in civil engineering structures. Computers and Structures, 80, 1667-1687.

HAZUS 99-SR2, 1999. HAZUS 99, Estimated annualised earthquake losses for the United States. Federal Emergency Management Agency (FEMA), Washington, USA. Available in: <http://www.fema.gov/plan/prevent/ hazus/ > [last access: June of 2004].

Hurtado, J.E. and Barbat, A.H., 1998. Monte Carlo techniques in computational stochastic mechanics. Archives of Computational Methods in Engineering, 5 (1), 3-30.

Infocca, 1999. Funcions d'informació de Barcelona $i$ cartografia. Spain: IMI, Ajuntament de Barcelona.

Irizarry, J., 2004. An advanced approach to seismic risk assessment. Application to the cultural heritage and the urban system of Barcelona. Thesis (PhD). Universidad Politécnica de Cataluña, Barcelona, Spain.
Irizarry, J., Goula, X., and Susagna, T., 2003. Analytical formulation for the elastic acceleration-displacement response spectra adapted to Barcelona soil conditions. Barcelona, Spain: Institut Cartogràfic de Catalunya, Technical report.

Kappos, A., Pitilakis, K., Stylianidis, K., and Morfidis, K., 1995. Cost-benefit analysis for the seismic rehabilitation of buildings in Thessaloniki, based on a hybrid method of vulnerability assessment. In: Proceedings of 5th international conference on seismic zonation, Nice, France, 1, 406-413.

Lantada, N., 2007. Evaluación del riesgo sísmico mediante métodos avanzados y técnicas GIS. Aplicación a la ciudad de Barcelona. Thesis (PhD). Universidad Politécnica de Cataluña, Barcelona, Spain.

Lantada, N., Pujades, L.G., and Barbat, A.H., 2008. Vulnerability index and capacity spectrum based methods for urban seismic risk evaluation. A comparison. Natural Hazards. (DOI: 10.1007/s11069-0079212-4).

Lungu, D., Aldea, A., Arion, A., Vacareanu, R., Petrescu, F., and Cornea, T., 2001. European distinctive features, inventory database and typology. Work package 1 of RISK-UE project, European Commission, EVK4-CT2000-00014.

Masure, P., 2003. Variables and indicators of vulnerability and disaster risk for land-use and urban or territorial planning. IDB/IDEA program on indicators for disaster risk management, National University of Colombia, Manizales. Available from: http://idea.unalmzl.edu.co.

Mata, P., Oller, S., and Barbat, A.H., 2007. Static analysis of beam structures under nonlinear geometric and constitutive behaviour. Computer Methods in Applied Mechanics and Engineering, 196, 4458-4478.

Mata, P., Oller, S., and Barbat, A.H., 2008. Dynamic analysis of beam structures under nonlinear geometric and constitutive behaviour. Computer Methods in Applied Mechanics and Engineering, 197, 857-878.

Mena, U., 2002. Evaluación del riesgo sísmico en zonas urbanas. Thesis (PhD). Universidad Politécnica de Cataluña, Barcelona, Spain.

Milutinovic, Z.V. and Trendafiloski, G.S., 2003. Vulnerability of current buildings. Work package 4 of RISK-UE project, European Commission, EVK4-CT-2000-00014.

Moreno, R., 2006. Análisis no lineal estático y dinámico para la evaluación del riesgo sísmico en edificios: aplicación a diversos escenarios sísmicos de Barcelona. Thesis ( $\mathrm{PhD})$. Universidad Politécnica de Cataluña, Barcelona, Spain.

Olivera, C., Redondo, E., Lambert, J., Riera Melis, A., and Roca, A., 2006. Els terratrèmols del segles XIV i XV a Catalunya. Barcelona, Spain: Institut Cartogràfic de Catalunya, Generalitat de Catalunya.

Oller, S. and Barbat, A.H., 2006. Moment-curvature damage model for bridges subjected to seismic loads. Computer Methods in Applied Mechanics and Engineering, 195, 4490-4511.

PGS-1, 1968. Norma sismorresistente P.G.S.-1. Spain: Comisión Interministerial de la Presidencia del Gobierno, Decreto 106/1969 de 16 de enero de 1969.

RISK-UE, 2004. An advanced approach to earthquake risk scenarios with applications to different European towns. RISK-UE Project, ICC/CIMNE, WP08, Application to Barcelona.

Saaty, T.L., 2001. Decision making for leaders the analytic hierarchy process for decisions in a complex world. Pittsburgh, USA: RWS Publications. 
Secanell, R., Goula, X., Susagna, T., Fleta, J., and Roca, A., 2004. Seismic hazard zonation of Catalonia, Spain integrating uncertainties. Journal of Seismology, 8 (1), 24- 40 .

Singhal, A. and Kiremidjian, A.S., 1996. Method for probabilistic evaluation of seismic structural damage. Journal of Structural Engineering ASCE, 122 (12), 1459-1467.

Vielma, J.C., Barbat, A.H., and Oller, S., 2008. Comportamiento sísmico de edificios de hormigón armado de ductilidad limitada. Hormigón y Acero, 59 (248), 87-101.
Whitman, R.V., Reed, J.W., and Hong, S.T., 1974. Earthquake damage probability matrices. In: Proceedings of 5 th European conference on earthquake engineering, Rome, Italy, 2531.

Yepez, F., Barbat, A.H., and Canas, J.A., 1996. Simulación de escenarios del daño sísmico en zonas urbanas. RevistaInternacional de Métodos Numéricos para Cálculo y Diseño en Ingeniería, 12, 331-358. 